\title{
Equitable Growth and Poverty Alleviation: Lessons Learned from Korean Experience
}

\author{
Chatyong Park ${ }^{* *}$ AND) KHAIJd IKRAM ${ }^{* * *}$
}

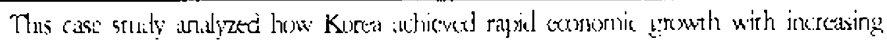

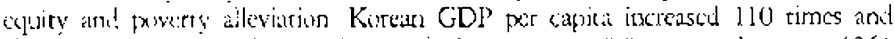

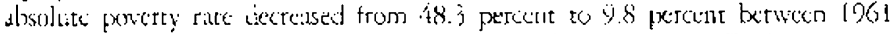

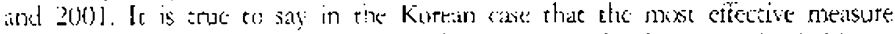

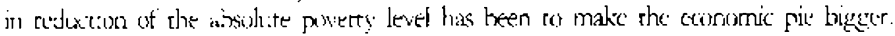

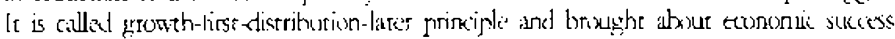

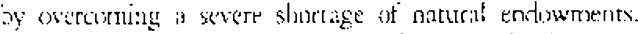

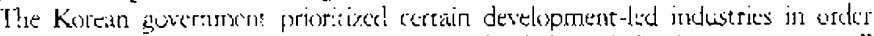

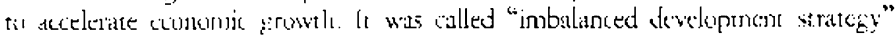

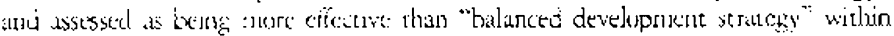

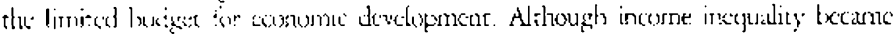

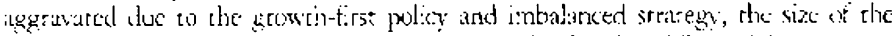

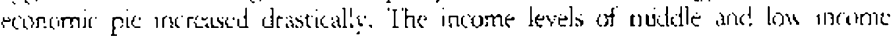

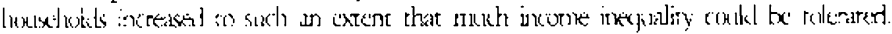

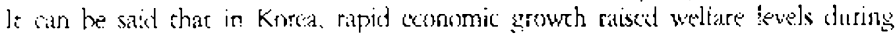

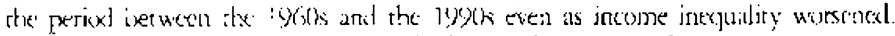

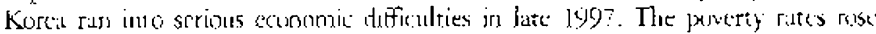

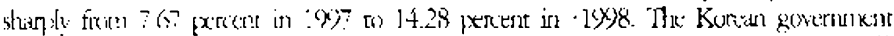

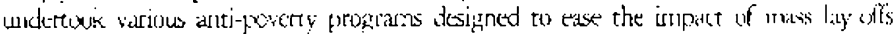

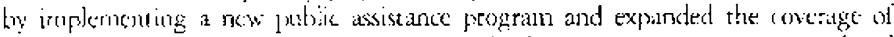

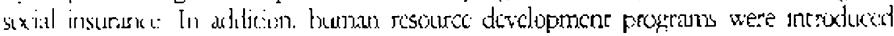

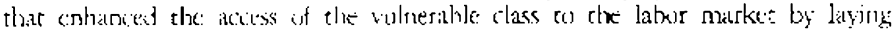

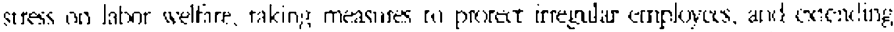

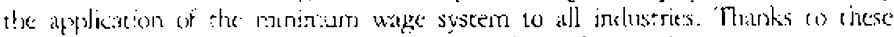

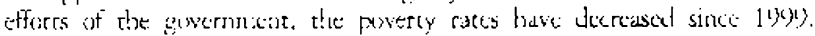

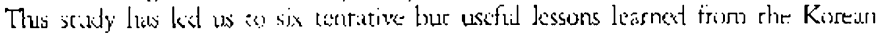

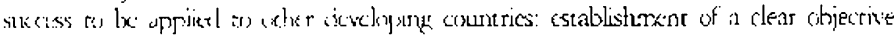

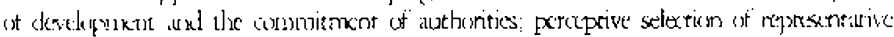

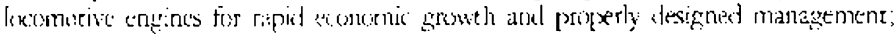

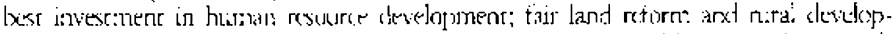

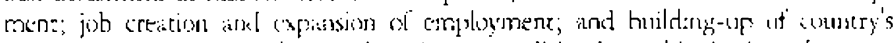

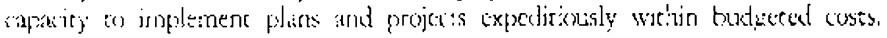

Kermords: economic development, poverty reduction, income discriburion, Koreun economy, development strategy

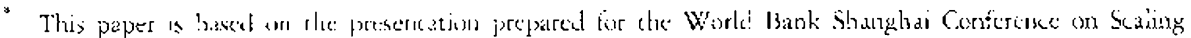

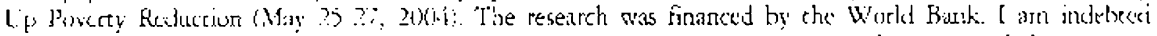

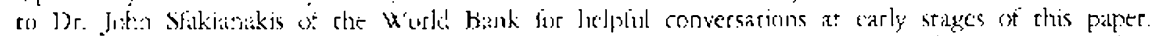

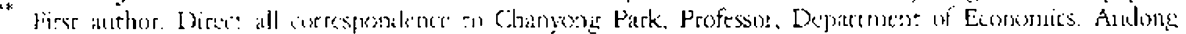

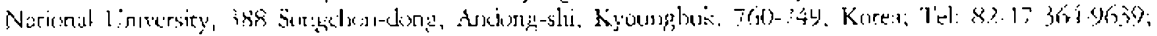

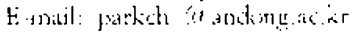

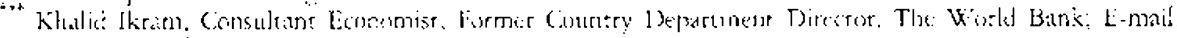

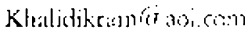




\section{INTRODUCTION}

$\mathrm{T}$ his paper has been prepiled to present the lessons learned on how Korea has successfully actueved a rapid ceonomic growth and dramatic poverty roduction during the past four derades. Such remarkable povercy reduction during such at short period was possible thanks to the rapid increase of mean income by equally rapid econorric growth. Of course, jucrease of income does not necessarily result in foverty alleviation as cridenced in many develepping countrics. However, it is truse to saty in the Korean catse that the most offective mesisure in reduction of the ahsolute povery lewel has becn to make the conomic pie bigger. It is allicd growth first distribution later principle and hrought abuut economic success by overcoming a severe shortage of natural contowments.

The experience of korea in combining fast econonic groweh with rapied redaction in powerty is paralleled by fex other councries. It is even more inpressive considering that less than 25 perecent of the country is suitable for agriculture us uther economic: activities, and that Korea possesses very few ratural resources. At the same time: Korca lad to recover from a dewascacing civil war in which the major part of its indristructure was descroyed. The sucess attained by Korca was brought about almost entirely as a result of adopting the right ecunomic policis, taking advantage of whatcer opportunities presented themselves, and a disciplined work effort. Moreover, this strategy has been continumusly maintained since the early $1960 \mathrm{~s}$.

The paper consists of five chapters. 'l'he second chapter gives a summary of the rationale of (dewelopment strategy and irs pelinical aspects with special cruphasis on macereconomic outcomes, using the most recent data available. The third chapter lays out a general view of poverty: lewel and a powerty profile by age. educational attainment and sender of the houschold head. It also describes characteristics of the poor hy highlighting economic and social aspects. This dhapeer shows the policies ter reducing poverty causced by the 1997 economic erisis and their limitations. The fouth chapter of the paper describes how Korea reduced poverty with its development strategies. It comments on governiment folicies related to poverty rechuction and conomic prowth by inciating discussion on the goverument's rese in economic development and the

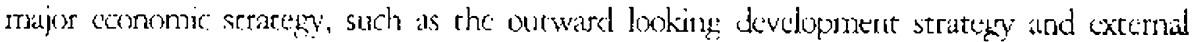
borroxing. 'This chapter also describes how the success of Korea in overconning its powr enduwmene of nacural tesouress uwed a greate deal to its policies of human resourec dovelopment. Furtherowore, it discusses agricultural developmont with land reform and exprassion of employment. The fifth chaper contains the concluding remarks.

\section{Il. DEVEI.OPMENT STRATEGY OF KOREA}

\section{Rationale of Development Strategy and lts Political Aspects}

The Korean seonomy has been marked by in relively high growth rate since the 
First Five Year Development Plan (1962.1966) was set out. The plan was established against the dark backdrop of the country's industrial plants and agricultural land damaged and impoverished by the Korcan Civil War (1950-1953). Even several years after the armistice: Korea's economic situation was far from promising. $\Lambda$ t that time, most people had naturally been wating for the appearance of a scrong national policy to help them escals poresty. Linder the socio-conomic situation, the regime brought forward two representative mottos "escape from the vicious circle of poverty" and "modernizing the fatherlind." The development strategy wis managed by strong government leadership in order to improve the deficient market economy system of those days. One of the most ubvious points of the backward nature of the Korear cconomy was that the marker conomy was not very matute at that time.

'The Korean goverunent decided to expand the country's infrastrucrure, build up its industrial foundation, secure the required budget by fercign capital and carry out an industralization policy by concentraring investment on export led industries. Also, the Korean government prioritized certalin development lad industries in order to acclerate ccomomic growth. It was called "imbalanced development strategy" and assessed as being mote effective than "ballanced development strategy" within the lirsited budget for economic develupment. However, the strategy was not nelconed by all people at the beginning, so it was necessan' to appease parricular social groups that felt relacisely deprived by the imbalanced development strategy. even under the authoritarian regine of those days. The growth-first-distribution-larer principle might be considered as a kind of promise that would provide the relatively deprived sroups with a hope of inporeving their lives in the near future. As at result, it proved helpful in forging a consconsus on the national development strategy.

Howerer, the development strategy sexened to lex established not undy for the purposse of rapid economic growth and escape from absolute poverty, but also due to sume political reasons unavodatale to the regime. The military regirme, which took political power by miliary coup in 1961, must bave judged that the escape from absolute: poverty by rapid incone increase could be the sole measure on justify their miliary coup and that the rukers would ulimatcly recoves from a lack of political legitimacy. In fact, cetain portions of the popalation, especially the college students and the intellectuals, were ayalinst the military regine and the United States was unhappy with the military coup and was interrupting atid flows for leverage (Krause L. B. 1997). Also, there was a thinking within the regince that only theough rapid economic growth could Kusea be cotirely independent from the historical scars left by the Japanese occupation. Also the result of rapid growth would establish a grood vantage ground ro deal with Norrty Korea.

Some observers consister that much of Korea's planning and policy.making had been formulated in the sladiow of what was happening, of said to be happening in the North. It was said lhat Kurcia, from the very beginning of its planning, had to paly much more antention to squestions of equiry and povery alleviation than pxerhaps other countries had to, because rhe sheroric, ar least, from Vorth Korea was that 
they were developing an equitable and classless socicty. It is true that the initial planning of North Korea appears to have been quite successful. The cwo systems, those of North and South Korea, were in comperition. However, it would never do for South Korea to be seen to be lagging behind the North in terms of equity, while escaping from absolute povery through rapid econonic growth. At the bxginning of the economic development in the 1960s. South Korea already had very equalized incomes and assets due to land reform and total destruction of the industrial facilities during the Korean War. So the most important objective in South Korea was an increase in incone. Also, another reason why Kotea was not interested in North Korea's economic equalicy was that most Koreans belicving in socialist iderology left South Korea to emigrate to North Korca during the Korean War. As a result, Souch Korca could, from the very beginning of its planning, pay attention primarily to questions of economic growth. The economic principle of "growth-first-distributionlater" coukd be found also in mactoecononnic policy with high inflarion and a fiscal policy with regressive income tax rates.

Although income inecuality became aggravated during conomic developmente the size of the economic pie increased greatly. Park (1992) reports that the income level of niddle: and low income houscholds increased to such an extent that much incoenc: incquality could be tolcrated. It can be saict that in Korea, rapid economic growth raised weltare levels during the period between the 1960s and the 1990s, cren as income inequalioy worsened. Alos, the Korean detelopment strategy atecelerated economic growth and creatcd many jubs that cuuld provide the uncmployed with a stable income, and ultimately brought about an expansion of social welfare.

\section{Main Macrotconomic Outcomes}

The development strategy was effective in raising the Korean comomy. Rapid Economic growth started just after the outset of the First Five Year Development Plan. For example, per capita GDP increased by about three times for the period between 1961 and 1970, and uxer five times for the 10 year period between 1970 and 1980. The high groweth rase continued until just before 1997 when the Korean conony was hit by an economic (risis. Also, Korea became a councry that couk boast the highest GilP grouth rate in the world. However, the extermal emironment did not let the Korean economy drive always on a kevel road. The Korcan economy had some biter experiences to he faced with a few severe crises, such as the first and second oil shocks, the Kwangju Lprising and the 199? economic crisis. Nonctheless, those socio-economic obstakles were nox atble to drascically slow down the locomocive force of the Korean econnmy. In the 1990s, the CiDP grew by wee $5 \%$ every year except for 1998. In 1900 and 1991, the growth rate for the Gidp was y.o\% and 9. $2 \%$ respectively, but tor the following year it fell $50.4 \%$ and this was mantained at a similas level in 199). After the onset of the fintamcial crisis, Korea wuffered a scrious ecomonic downturn. However, the: Kurean gosernment implementad drastic 
reforms to correct the structural weaknesses inherent in its economy. The economic restructuring was carried out in the corporate, financial and labor sectors in order to promote transparency, efficiency and flexibility. Starting in 1\%\%, the Korean ecomomy has shown a trend of rapid recovery. The growth rate, after dipping to $6.7 \%$ in 1998 , soared to $10.9 \%$ in 1999.

Korea's exports grew from $\$ 55$ nillion to $\$ 22$ billion, an annual growth rate of nearly 40 percent. Nor surprisingly, the composition of exports changed, from less than 10 percent accounted for by manufacturing in 1962, to 90 percent in 1980. In 1962 the valuc of Korea's trade was only $\$ 477$ million. In 1965 , it passed the $\$ 638$ million mark; in $1970, \$ 2.8$ billion; in $1975, \$ 12.1$ billion; in $1980, \$ 39.8$ hillion; in 1985, \$61.4 billion, and in 1990, \$135 billion. In 1960, Korca ranked lolst among the world's exporters; roday it is the 12th biggest.

'Table l. Obtraj.t. economic: Perbokmance

\begin{tabular}{|c|c|c|c|c|c|c|}
\hline Year & $\begin{array}{l}\text { Per Capica } \\
\text { GDP:" } \\
\text { (LS\$) }\end{array}$ & $\begin{array}{c}\text { (GI)P } \\
\text { Gronth Rate } \\
\text { (统) }\end{array}$ & $\begin{array}{c}\text { Tracle" } \\
\text { (Exports + lmports) } \\
\text { (Billion US\$) }\end{array}$ & $\begin{array}{c}\text { Savings } \\
\text { Rate } \\
\text { (\%) }\end{array}$ & $\begin{array}{c}\text { Investments } \\
\text { Rate }^{1)} \\
(\%)\end{array}$ & $\begin{array}{c}\text { Gini } \\
\text { Coefficients }\end{array}$ \\
\hline 1961 & 82 & 5.6 & 0.357 & 11.7 & 120 & - \\
\hline 1962 & $8 ?$ & 2.2 & $0.4 ?$ & 11.0 & $11 . \dot{8}$ & - \\
\hline $\operatorname{lig}(13$ & 100 & 9.1 & 0.613 & 1.4 & 17.0 & - \\
\hline 196 & 103 & 9.6 & 0.5 .73 & 140 & $13 . ?$ & \\
\hline 1965 & 105 & 5.8 & 0.638 & 13.2 & 14.1 & . \\
\hline 1970 & 249 & 7.6 & 2.819 & 18.1 & 2.4 .3 & - \\
\hline 1975 & sy? & 6.5 & $1 ? 4$ & 18.1 & 28.6 & $0.340^{!}$ \\
\hline 1980 & 1,598 & -2.1 & 3i). & 13.2 & 31.9 & $0.354^{21}$ \\
\hline 1085 & 2,229 & 6.5 & 61.1 & 29.8 & .00 .3 & $0.384^{-1}$ \\
\hline 1900 & 5,386 & 90 & $13 \cdot 1.9$ & 35.9 & 37.1 & $0.345^{2:}$ \\
\hline ]ין] & $\{(, 810)$ & 9.2 & 153.4 & 36.1 & 39.1 & $0.393^{\circ}$ \\
\hline 19)? ? & $\therefore 183$ & 5.4 & 196.4 & 34.9 & 36.8 & $0.36 \mathrm{j}^{2:}$ \\
\hline 1903 & 7,811 & 5.5 & 1600 & 35.2 & $35 . \%$ & $0.36 ?^{2}$ \\
\hline $1 \%) \cdot \hat{t}$ & 8,998 & 8.3 & 198.4 & 352 & 36.1 & $0.363^{2:}$ \\
\hline $10 \%, 5$ & 10,823 & 8.9 & 260.2 & 35.5 & 37.3 & $0.370^{1:}$ \\
\hline 1496 & 11,385 & 6.8 & 2880.1 & 33.8 & 38.1 & $0.377^{9}$ \\
\hline Jyis7 & 10,315 & 5.0 & 280.8 & 334 & 34.4 & $0.369^{13}$ \\
\hline lyes & $6,7,44$ & -6. & 225.6 & 33.9 & 21.3 & $0.390^{\circ \prime}$ \\
\hline$!(y)(x)$ & 8,595 & 109 & 2651 & 329 & 26.9 & $0.398^{13}$ \\
\hline $20 x$ & y:io! & 9.3 & 332.4 & 32.4 & 79.3 & - \\
\hline 2001 & 9,000 & 3.0 & 201.5 & 36.2 & 27.6 & - \\
\hline $2000 ?$ & 10,013 & 6.3 & 314.6 & $29 . ?$ & 26.1 & - \\
\hline
\end{tabular}

SOJJRC.: 1) Bank of Korea, Nitional stattst it al Office:

2) Park and Kim (1<3)

3) Park, Kurn, aud Kien (190)j

$\therefore$ Park and Kim i 2003 ; 
Donestic investment can be financed by both domestic and fureign savings. However. at the heginning of the first plan, a shortage of savings was one of the most serious econonic problems, so that it was resolved, in part, by recognizing the relationship between inflation and the real rate of interest. According ro Cole and Park (1983), monetary reform reduced the inflarion rate and estahlished a positive real deposit interest rate of between 15 and 20 percent until the early 197(15. The savings rars. responded and rose from the $11-14$ percent in the carly 1960s to 20 percent by the end of that decade (Krause L. B. 199?). In 1991, it was recorded at 36.1 percent, which has been the highest rate to this day.

With regard to incone distribution, (ini coetficients showed a sharp increase of income incyuality during 1975-1990, and then a decrease until 1993. The Korcan government accelerated trade as a measure to increase pesple's income levels during times of development. Mah (2002) examined the impact of trade on income clistribution from 1975 to 1995 in Korca and found that when foreign trade increased, the Gini coefficients tended to increase. The result of Mah's analysis supports the fact that when absolute poverty reduced as income level incteased. income incquality was aggravated with growth oriented policy (inclioling texport-led policy).

Howerer, Kurea has often been considered as a country that has retained an equitable distribution from the initial suge in the 1960 s. This assessment likely stems from a lack of income data of whole lowscholds. For instance, "Family Income and Expendirure Survey" is a representative incomx surey in Korca. It has released income data annually since 1963 . Huwever, the survey covers only urban satiry and wage carners cxcluding self-employed people. ' l'hat is, unly income inequality among salary and wage carners could be calculates, making it impossible to produce statistics on the high income of the self-cmpleryed and the low income of the uncmoployed hit by the conomic downturn.

\section{POVER'IYY RLIEVIATION}

\section{General View on Poverty and Income Distribution}

Table ? lisplays the moilence of poverey in Kurea during $1961-2001$. There are two kinds of absolute porerty rates show'r in che table. They are estimated based on different purerty lines by different authors. The results are naturally different from eash other. Howerer; rhey ase urilized as they are, because it is noc casy to get consistent absolute poverty rates for a longeterm period. Even with this methued, its general trend, at lease, can be noted. 'The eable shows a specticular decline in absolute powerly rate trom 48.3 perent in 1961 to only 7.31 percent in 1996. Honvever. the absulute poverty rate increased in 1i)g? as a result of the economic arisis. reaching 14.28 percent in 1998 hetore dropping again to 9.84 percent in. 2001 . 
As shown in the talle, the relative poverty rate, estimated with three different puvercy lines (40 percent, 50 percent and 60 percent of the average income), was 9.7 percent, 18.68 percent and 28.93 percent respectively in 1975 , and then recorded 13.09) percent, 22.22 percent and 32.12 percent in 1995. While absolute poverty had been drastically reducel during this period, relative puerty had incrased.

It was found that there was high cortelation between the relative povercy rate and income distribution (see Tables 1 and 2). The relative poverty race and Cini coefficients both increased during 1975-1985 then the relative poverty rates decreased until 1995, but Gini coefficients concinued to inctcase until I\%), and then decreased with the relative povery rates until 1995. 'This explains that the relative poverty rates rose sharply with the aggravation of income incouality during 1975-1985, and then decrased due to the reduction of incone ine puality during $1990-19195$. It can be salid that absolure poverty was alleviated thanks to the rapid growth of incone, but relative poverty was not reduced as much as absolute poverty due to the increasc in income inequalicy in Korea.

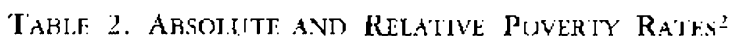

(Line: peterest)

\begin{tabular}{|c|c|c|c|c|c|c|}
\hline & \multicolumn{3}{|c|}{ Abssilute Povercy Rate } & \multicolumn{3}{|c|}{ Retlative Poverty Rate } \\
\hline & Fstim & alted & & 40 percens of the & (1) percent of the & 60 percent of the \\
\hline & Poverg: & Rate ${ }^{3}$ & Poverty Rale & ayeribge income & average income & areane income \\
\hline $1: 161$ & & $4.3^{31}$ & & & & \\
\hline 1965 & & $(0.9)^{3}$ & & & & \\
\hline [y? ? & & $23.6^{2}$ & & & & \\
\hline $19 ? 5$ & $21.52^{\circ}$ & & & $4.7 i^{i i}$ & $18.68^{11}$ & $28.53^{11}$ \\
\hline li) & $15.25^{\circ}$ & 1) 81 & j.: & $13.82^{1:}$ & $1.88^{\prime \prime}$ & 3]. $4 i^{11}$ \\
\hline 1985 & $1 \times .50^{\prime}$ & & $5.6^{\circ}$ & $1: 9:$ & $2535^{31}$ & $3663^{1}$ \\
\hline 11.588 & & $1.5^{: 1}$ & & & & \\
\hline 15) & $: 9.7\}^{\prime}$ & & $5.3^{\prime}$ & $1 \ldots$ & $21.11^{6}$ & 1. \\
\hline $15 x) 3$ & & $? .64$ & & & & \\
\hline 1609 & $8.7: 1$ & & $3.4^{1}$ & $13\left(0^{\circ}\right)^{\circ}$ & $22 \ldots 22^{1}$ & $32.12 \div$ \\
\hline $140 \%$ & $3.1]^{-2}$ & & $j . j^{11}$ & & & \\
\hline lyce: & $\therefore 6:=$ & & 3.]^{11}$ & & & \\
\hline 1908 & $1428^{\prime \prime}$ & & $\bar{i} .2^{\prime \prime}$ & & & \\
\hline$(1)(y)$ & $13.67^{\prime \prime}$ & & 1. 1" & & & \\
\hline 200ì & $0.39^{\prime \prime}$ & & $366^{\prime \prime}$ & & & \\
\hline $20(1) 1$ & $9.81^{3}$ & & & & & \\
\hline
\end{tabular}

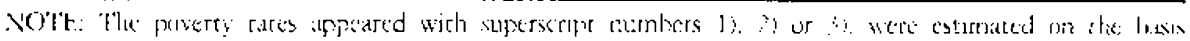

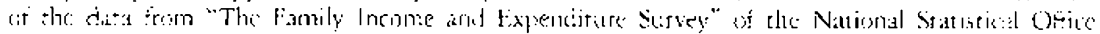

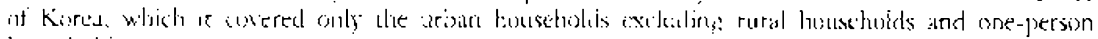
hroustrisilis

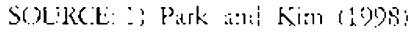

2) Park. Kiur: : alı! Kin: !ly(jy)

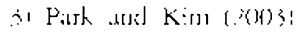

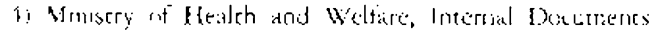

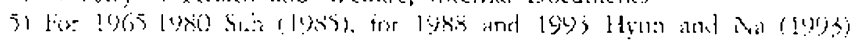


A comparison between the alssolute poverty rate and the administrative poverty rate (poverty rate for public assistance recipients) revealed a considerable gap between the two. This can be attributed ro several factors. First, to be eligible for public assistance applicants must meet nut only income criteria that are based on the porverty line, but also the property criteria, su some of those who qualified under the income criteria might actually be cxcluded if their property value exceed the maxinum property limic. Second, even these who qualify for both income and property criteria can be excluded if they have livelihood support from their legally responsible supporters. If such excluded persons were added to the calculation, the two rates are likety to be eloser to cach other.

\section{Characteristics of the Poort}

Poverty is highly related to peoplc's cconomic activity. A litcle over half of the public assiscance recipiencs, 51.5 pcrcent of houschold heads and 57 percent of the household members, are conomically active (see 'able 3 ).

Anong the conomically acrive recipients, the cmployment rate is 69.3 percent for household heads and 64.5 percent for household mombers. In other words, about one third of economically active recipients are uncmployed. This unemployment rate is much higher than that of the total population, which was 2 percent in 1995. It means that the high unemploymcot ratc is onc of the most important causes of a poor economic situation. The details are displayed in Table 3

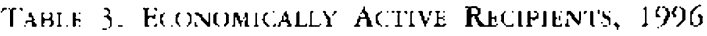

\{linit: Plorent

\begin{tabular}{|c|c|c|c|}
\hline & \multicolumn{2}{|c|}{ Fromomically Active } & \multirow{2}{*}{ Fcomomically Inactive (C) } \\
\hline & Eomployed $(A)$ & L'nenployed (B) & \\
\hline He'ad & $37.7(69.3)$ & $16 \times(30.7)$ & 45.5 \\
\hline Nember & $36.8(6.5)$ & $2(0.2(39.5)$ & 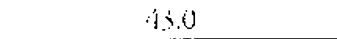 \\
\hline
\end{tabular}

No[l:: Numbers in fareathests inducto the froportion o: the employed and the t:nempioyed to the commically active nopulation.

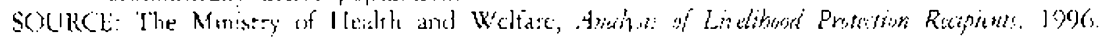

Poor health condition is anorher atributing facror of poverty, because it determines one's capabiliry to work. A survey shows that unly 51 percent of recipients are healthy, arouad 20 percent are either sick or disabled, and 24 percent have other types of illness, indicating that almose halt of the recipients are either disabled or sick.

TABLE 4. HEALTH STATL'S OF RECIPIENTS

(Linit: Pertent)

\begin{tabular}{|c|c|c|c|c|}
\hline & Healtly & Disabled & Sick & () ther \\
\hline Heckd & is.6 & $! 3 !$ & 15.6 & 329 \\
\hline ل & $51 . t$ & s.? & 10.9 & $29 .[3$ \\
\hline
\end{tabular}

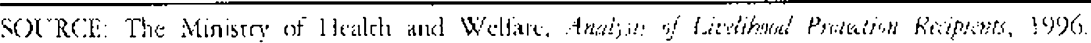


Education, as well as skills, is cnucial to finding a job. Most puthlic ansistance recipiertes have less than ren years of education. Abour 77 percent of household heads have no more than an elemerntary sthool colucarion, and must of them bave less than junior high school education. A total of 80 percent of all houschold members have: no smore than a junior high school cdecation. lack of cducation is a major obstacle for them in finding a well-pated or stable jols. 'lhese figrures indicate that the uverall educational level of recipienes is low.

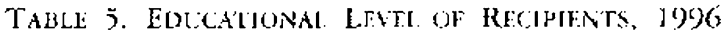

(Inis: Priti:ut)

\begin{tabular}{|c|c|c|c|c|c|}
\hline & No Education & Elementary & Junives Middle & lligh School & Juthiot $(v) l$ ege \\
\hline Head & $\therefore 6$ & $3 y$ & Y.R & $\because !$ & 0.6 \\
\hline Nall & 352 & $\because 1$ & i) 0 & 1.1 .6 & 1.1 \\
\hline
\end{tabular}

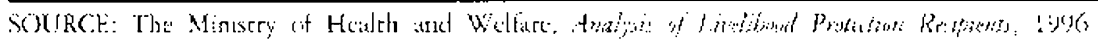

The most common cause of poverty in Korea is lack of work capacity. As lable 6 shuws, this can arise from age (too old or tou young). illows, disability, and not

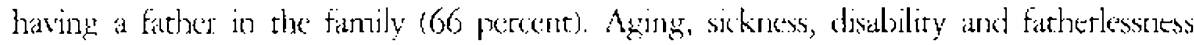
constitute the prionaty factor in poverty. The second cause is lack of education, work experience and skills, even though the recipients are ciapalde of working (29) percent). To be empleyed, especially with secure working conditions, cducation, work cxperience and skills are tequired. Persons without those chenents have difficulty finding jobs and eheir risk of hecoming prose is increased. 'The third cause is rhe unemployment of recipients with sone skills. Only 5 percent ul them tall intu this catcrory. Since uncmployed persons with skills can casily find jubs, their chances of encrging from povercy are ligglee than most obler recipienes withoue any skills. Thus, most people

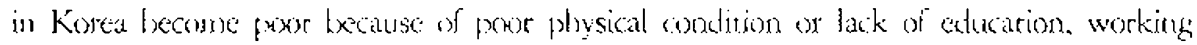
experience and skills.

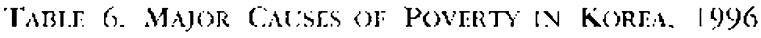

(Linis: Percicle)

\section{Major Causes of Poverty}

Proporcion

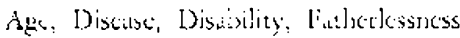

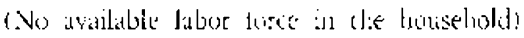

66,4

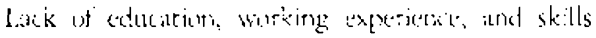

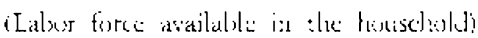

28.5

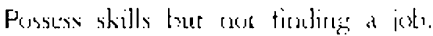

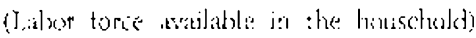

5.1)

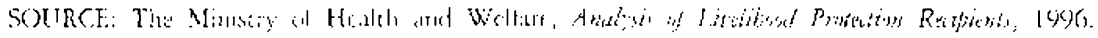

To sum up, the bighest incidence of powerty in Korca occurred anong families headed Ly persons of low educational attainment, and those headed by unemployed or undercmployed personts. Age is a significant factor, in that poverty is higher in 
families headed by elder persons. High sates of poverry are found in families heacted by single mothers with dependent children. The majority of the poor in Kurea live: in citics.

\section{The 1997 Eronomic Crisis and Poverty Reduction Strategics}

After a long period of rapid comomic growth, Korea ran into serious economic difficulties in late 1997 . Companies were forced to carry out corporate restructuring to retain their competitiveness, leaving an unprecedertedly high rate of unemployment in the process. As shown in 'lable 2, the poverty sates rose sharply from 7.67 percent in 1997 to 14.28 percent in 1998 due to the 1997 conomic crisis. The poverty' rates have decreased sicce 1999, however, the povery rate in 2001 was still higher than that in the years prior to the econonsic crisis.

'Table 7 shours current income-povery sate by age of household head. ${ }^{5}$ The incidence of poverey had been highest for houseluolds headed by people aged 60 or over until 2(0)1. Lutil loys, households of the lowest porerty sate were headed by thuse in their 50s. Beginning in 1999, households led by those in their 40 s were found as have the lowest porerty ratc.

Berween 1906 and 1997, the povercy rate of households led by those in thesi 4 (os made up 7.89 percent of the total households and it was down 107.88 percent. However, housetholds led by poople of other age groups, recorded increases in poserty rate.

The poverty level of houscholds headed by those aged 60 or older was higher than these headed by wher age groups. The analysis also showed that generally. houscholds led by those in their 50 , had been aftected the most by the coonomic crisis.

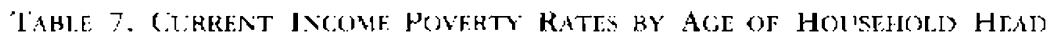
(ALl HOCSLLIOLDS)

\begin{tabular}{|c|c|c|c|c|c|c|}
\hline & $\begin{array}{l}20 \text { and } \\
\text { below }\end{array}$ & 301. & its & $50 \mathrm{~s}$ & $\begin{array}{l}60 \text { and } \\
\text { over }\end{array}$ & $\begin{array}{l}\text { Whole } \\
\text { Households }\end{array}$ \\
\hline 13) & 1200 & 9.59 & 7.89 & $\{1.5 \%$ & 16.95 & 9.45 \\
\hline libis & 12.11 & 980 & 7.88 & 5.70 & 1781 & 9.52 \\
\hline [4) & 19.68 & 14.93 & $12.1]$ & i 1.98 & $240 \%$ & 15.80 \\
\hline $1, y 0 y$ & 11.38 & 1.t.66 & I g.'1 & ! jot & 32.39 & 15.56 \\
\hline $2\{k(16 ;$ & 10.23 & 11.32 & $9.5:$ & 00.26 & 26.97 & 12.25 \\
\hline ?mol & 19.9 & $10 . \vdots 1$ & 1).2's' & 3.29 & 27.55 & $\| 1.81$ \\
\hline
\end{tabular}

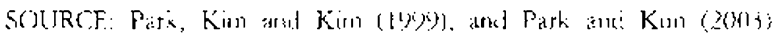

In 1997, households led by those aged 60 or more recorded the highest poverty rate at 17.81 percont, followed by those ked by heads aged 20 or less at 12.91 . percent, $30 \mathrm{~s}$ at 9.80 percent, a0s at 7.88 percent, and $50 \mathrm{hs}$ at 5.70 percent. In 1998 
ac the peak of the conomic crisis, houscholds headed by persons aged 6o and Deet showed the latgest poverty rate of 2.03 percent, followed by those with heads in their $20 \mathrm{~s}$ or kess, ther $30 \mathrm{~s}$, 40), and 50 s respectively. Prior to and after the crisis as well, those houscholds headed by persons in their 50 s showed the lowest poverty rate.

'lihe review of curcent incorne-poverty rate based on educational attaiments clearly show's that the more educated, the lower poverty tate (See '[ahle 8). In orher words: college graduates are less likely to be poorer than high school graduates, and high school graduates are less likely to be poorer than junior high school graduatcs.

Between 1497 and 1948, or righe before and afeer the economic crisis, the trend continued and the poverty rate diminished as the educational level increased. During the sance period. poverty rates among households headed by junior high school graduates incroased from 11.23 perecont to 19.68 percent. Poverty rate among high school graduates increased from 8.36 percent to $13.8 \%$ percent. Povery rate among houscholds heaked by clementary school graduates increased from 20.35 percent in 1997 to 28.87 percent in 1908.

When viewed from the standard of educational arcainment, houscholds headed by elenentary school graduates were the ones who suffered most from poverty. On the other hand, households headed by college graduates or higher, showed the lowest level of poyerty. In 1 y9y, when the economic crisis reached its peak, rankings of poverty in relation to extucational attaimment dict nos change. However, the ripple effects of the econonic downturn were nost apparent in houscholds beaded by minddle school graduates. and then those by high scturol graduates.

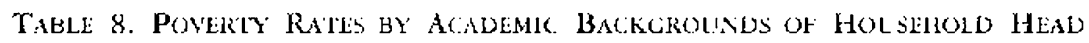
(AI.I. Hoxist:H(T).1)

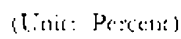

\begin{tabular}{|c|c|c|c|c|}
\hline & Elementary School & Middle: Schoos & Highs schoul & Eniversity and higher \\
\hline $39 \% 6$ & 19.26 & 111.78 & 8.79 & 5.77 \\
\hline 19y:- & 20.35 & $1: .33$ & 8.36 & 5.56 \\
\hline 194$)$ & 288 & ly.68 & 13.8: & 8.8 \\
\hline 1999 & 34.48 & $7, \ldots ?$ & 14.51 & 7.79 \\
\hline 20000 & 28.16 & 18.21 & 11.51 & 5.68 \\
\hline $20(x) 1$ & 27.07 & 16.18 & 11.65 & 5.39 \\
\hline
\end{tabular}

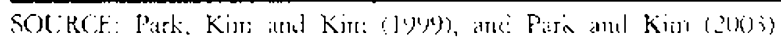

'The poverty rate varjed considerably between malt-headed and temale-headed houscholds. Table? shows that the poverey rate in malc-heaked houscholds was 7.57 perecent, as of 1997, while that in female-headed houscholds was alnust double, recording 15.86 percent. Gender-related poserty gap was narrowed to 1 . 68 rimes in 1998, but che gap has bece wikning since 1999. The problen of poverty was more serious for fermalc-headed houscholds than for male-headed houscholets. 


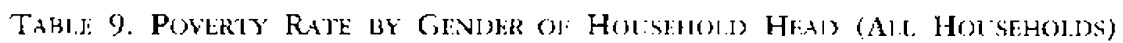

(Linit: Percent)

\begin{tabular}{|c|c|c|c|}
\hline & Malc (A) & feoviale (B) & $B: A$ \\
\hline $190 \%$ & 8.01 & $1 ? \therefore 49$ & 2.18 \\
\hline |ys: & 5.57 & $15.8 \%$ & 2.16 \\
\hline 1998 & 12.26 & 20.55 & 1.68 \\
\hline $19(9)$ & 13.94 & 23.18 & 1.66 \\
\hline 20000 & 10.95 & 18.5 & $1.6 \mathrm{x}$ \\
\hline $200:$ & 10.41 & $13, \leqslant 1 ?$ & 1.24 \\
\hline
\end{tabular}

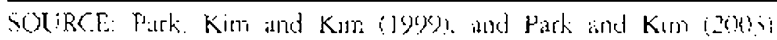

After the 1997 coonomic crisis, the government andertook vatious anti-poverty programs designed ro ease the impact of mass lay-offs, including temporary livelihood protection for thowe rendered johless. While orerall houschold incomes shrank, houscholds wirh lower income were most likely $10 \mathrm{sec}$ their incorre conttast even furcher. Likewise. the situacion worsened incone discribution and pushed those at the bottum of the micklle class down into the poverty dass, wistening the gap between the rich and the poor. The economic crosis in 1997 demonstrated weaknesses in the abiliey of the Kurcan asti-poverty systern to deat with external shocks.

The Korean growernment and ministries concerned with ant powerty policios crolved at new mextel for welfare tailorcd to the provaling circumstames of Kored. The (thanges made to the social protection systom reflected the desire to exiend benefits to all of sexiery and to updace the older sysem. This new model is known as "Producrive Welture."

Productine Welfare is an ideologry that seteks to secure minimum living standards for all low-incone households, provic? human resource developmene preserams eu suppore self-reliance of the poor, and guarantec a basic living stanklard by cxpanding the cowrage ot social insurance to all people. In shorr, Productive Welfare endeavors to improve the quality of life for all citiecns by pronueng seciat development and a fair discriburion of wealth. Thus, wherher policies based on Producive Welfare have stabilizet socicry through protection programs tis the poor and the unemployed is the best criterion for assessing the achievement of the straregy.

Mose assessments concur that Productive W' liare, regarded as a major pillar of national peliciss, did contribute significantly to overoming the diffeult situation. The main policies theough which the ideology of Productive Weftare was implemented were the Vational Busic Livelihuxel Sccurity Act (NBLSA and the expansion of the coverage of social insurance. In addition, buman resource development prograns were introduced thate coluanced the access of the vulnerable class a the labor market by laying sress on labor welfarc, ralking measures to protect itregular onployecs. and exemding the application of the minimum Wiber system co all industries.

Amonge the reforms of anti-poverey system, the introduction of the VBISA was at major change. 'lhe $\mathrm{NBLSA}$ stated sirte October 2000 als a replacement of the

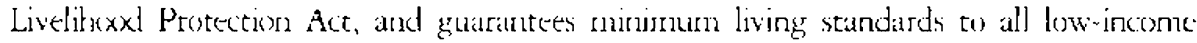


families with an income betew the official poverty line, irrespective of their ability to work. Hence all low-income carners with the alility to work also become eligible for benefits: unlike under she previous system. With the implementation of the NBISA, the number of livelihood payment beneficiaries tripled from $5,00,000$ in 1999 to 1.51 million in 2001.

Livelihoud payments under the NBISA are designed to provide supplementary payment to households with an income below the official puverty line. The amount of support is the difference between household income and the official poverty line. Civil rights were also enhanced as the NBLSA was made into a social duty. The NBLSA resulted in an inctease in the number of the Salf-Relicute Aat Center: from 6 in 1997 to 161 in 2001 and in the number of social workers frons 3,000 persons in 1997 ro 5,500 in 2001. Along with this, the importance of the Survey of Minimum Cust was also cmphasized.

The official poverty lines for the NBJSA benefriaries are defined in 'I able 10. Those who meet the criteria and do not have any family support will be chosen in the selection. The range of the farnily supporters is limited to inmediate family members, spouses, and any siblings who support them financially.?

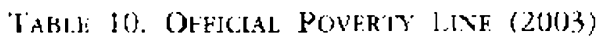

\begin{tabular}{|c|c|}
\hline Number of housebold members & Criteria (Korean Won) \\
\hline Ons & 355,774 \\
\hline Two & $5 \times 4,2] y$ \\
\hline There & 810.431 \\
\hline liviter & $1,01 \%, 4] 1$ \\
\hline Fis: & $1,159,070$ \\
\hline Six & $1.3079 .9(1) 4$ \\
\hline Swen ant more & Atd 1 20,000 per person increased \\
\hline
\end{tabular}

SOURCE: Ministry at Heis:

The social insurance system has undergone rapid changes since 1998. The rationale of this change is to: drastically reduce uncovered groups by applying the National Pension scheme to all people; integrate the management systems of the Heally linswsane

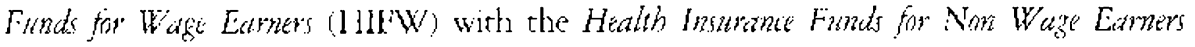
(HIFNW); and expand coverage of Employment Insurance and Industral Injury Insurance to all workplaces. As a result, anyone who has an income is now covered by the National Pension scheme, regardless of employment category. Now, cven if pension contribution is paicl only once, pension payment for the disabled and suriwors is permitted." In addition, the Ifealth Insurance system has been made more equitable by integrating different management systems. ${ }^{0}$ And by abolishing limits on periods for Healch Insurance services, onc can get medical service throughemt the year.ll

Since the 1997 economic crisis, economic recession and dramatic restructuring raised 
the unemployment rate. Accordingly, the expansion of Iimployment Insurance coverage was applied carlier than proviously planned, beginning March 1998, in order to provick uncmployment benetits even to workers at the workplace with 5 or mure persuns. Considering the scvere unemployment situation, the coverage was again expanded in Octolxe 1998, tu include workers at the workplace with four or less persons as well as temporary or part-tine workers. '? Beginning in July 2000, membership has become mandatory in Industrial Injury Insurance, even for the workplace hiring less than 5 persons. ${ }^{\text {" }}$ texpandert implementation of social insurance by reducing the mandatory employment period was aimed at exconding coverage to include temporary and daily workers.

Ender the Nittionad Pension scheme, temporrary, darly, and other part-1ime emiployees

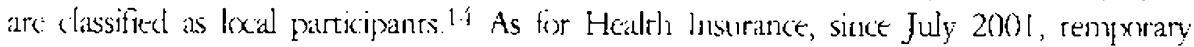
and daily workers were ransicred to the workplace participant group. Upon the initial enacement, Employment Insurance was not applied to those who worked for less than a threc-month period and kesi than 30.8 hrours a week. Since Octolxer 1998 , the mandatory employnent period was shortened to incluke dose who worked more (han) onte month and more than 80 hours per month (or more than 18 hours a weck).

'I tranks to the rclaxation of the requirement for employment period and the expransion of equlifying workplaces, the matginal workess's, who are not covered by social insurance, have decreased tor the past wo to three years. Despite the concentrited efforts to cxtend curctage of social insurance, a substantial number of persons still do not have access on income maintendere benefits under social insurance.

lemporary and daily workess cmployed for one month or less in all industries and those whis work less than 18 hours a week are not covered by employment Insurance. Koreals social insurance schemes had provited a protective umbrella in favor of salary and wage carners, hue it didne do the same for the lowest paid, temporary contract-based workers. Herree it is essential to figure out the rypes of gapses cxisting in the social insurance scheme and their impace on the system. It is also cissential to realixe that the grovernment's cfforts to expand the coverase of the four social insurance schemes for the prast wo or threc years have nor becrl sufficicine to overcome the problem of galps in the coverage and that the difficulty should be deale with on multiple fronts.

\section{HOW KOREA REDUCED POVERTY}

\section{Commitment and Credibility of the Government}

Pertaps the key factur in Koreit's sucess was the commitment of aluthorities at the highest level to economis development, and the strong perception that policies that had been announced would, in fact, be implemented. Korea has never lacked plans. The Office of Planning was established under the government of President 
Synkman Rhece as far back as 19/8; this office duly prepared a five-year plan (never inplemented), and revised it later (also not implemented). There were also numerous missions by foreign experes to advise on policies and to prepare platis (for cxample, the "Nathan Plan" submitted in 1953. bur never adopted). A threc-year plan was prepiared in 1960, but was first pustponed fire a year and then came into effect only for a tew months before the khec regime fell. The succededing grovernment of Chitng Myon also dirceded the preparation of a five-year plan in 1960; this was made redandaut by the military coup of May 16,1961 that brought President Park Chung Hee to power.

The Park regine put eonomic development unambiguously at the top of its proritics: in fact. President Park (1963) maintained that. "In human life: cconomics precedes policics or culture." Bur a strategy delivers benefies only to the extent that it is actually pue into effect. As Mason at et al. (1980) poine 1)ut, a vital lesson that other couneries can learn from Korca's experience is the improrance of establishing the governments credibility in the implenentation of announced policies. It has now been reduced almost to a truism that Korea's success owed more to its capaciry to inplement pulicis theur to fommulace plans. President Park, in addition tu strengthening the planning process, fatid yreat emptasis on carrying out announced policies. Pulicy implementation was accomplished through a rigorous strucure of rewards and punishments, inclading compulsion and administrative discrecion.

The result was at sharp incesese in the public's perception that the government moint what it said. According to a maior srudy of businessmen's perceptions of the firmness of the goverminent's resolve by Jones and SaKong $\mid 1 /(1980)$, only 3.2 perent of the respondents indicated that under Rhee decisions wers "always implemented," and 17.2 pereene believed that they were "almost alwass implemented." Contrast this with the Park periud: $7 x .2$ perene of the businessmen responded that decisions were "always implemented and that it was impossible to avoid complying," and 16.6 percent said that they were "Imost always implemented." his shitt in perception also made it asicer for the governomen eo implemene ies policies without having (1) calopt extrems: measures.

\section{High-Crowth, Outward Looking Development Strategy}

'The basic weapon for the rapid reduction of powerty was the acceleration in etse rate of GlDP growth. Between 1965-1991, the rate of growth of Korea's GDP was almost always abowe $?-8$ percent a year in real terms, and at periols exceded $)$ percent a yeur. A stratcey of light growth was adopted, and it was recognized that subli a strategy would require a very substantial increase in the rate of investment. However, Korea lacked the resources on finance this investment; these ressures would hare to be borsowed from atsorat. But borrowed texcernal resources have tis be refraid in toretgn exchange. The only way for Korea to obtain the necessary foreign exchange

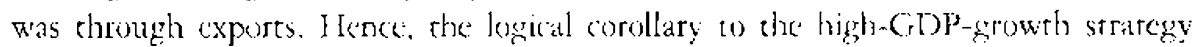


was at strategy that relied extensively on the rapid expansion of exports. Moreover, the outward looking strategy, in which Korea would have to compete vigurously in the incenational market, forced the country to pay continued atcention en mobilizing resources efficiently and increasing their productivity.

Some comparative figures furnished in Johnson (1987) highlight Korea's achicvements in carrying out its chosen growth stategy. In 1950, expressed in 1974 US dollars, Korea hat a per capita income of $\$ 1 \% 6$; compare this with $\$ 203$ for Eyypt, Nigeria with $\$ 150$, or Mexico with $\$ 562$. By 1980, Korea's per capita incone (again in 1974 US dollars) had shot up to $\$ 1553$ (an antual growth of 8.2 percent); Legpt's was $\$ 480$ (2.9) percent), Nigeriats $\$ 6.70(5.1$ percent), and Mexico $\$ 1640$ (3.6 perecont). Note that the last three are important oil producers. Between 1962-80. Koreais GNP grew at an annual tate of 8.5 percont in real terms. In pirticuar sectors, the groweth was coen more impressive: berween $1962-80$ value-idded in manulacturims increased at an average annual race of 18 petcent. Korea's cxports grew from $\$ 55$ million to $\$ 22$ billion, giving an annual growth rate of nearly 40 percent. Vot surprisingly, the composition of exports changed, from less than 10 perecent accounted for by manufaceures in 1963 , to 90 percent in 1980 . The result of this stratcery was a rapid transformation of rhe structure of the conomy, away from onc dominated by the agricultural sector into one in which manofacturing preduminated.

The fast growith, based on an outward-looking strategy, was fuxlled by a very rapid expransion ol exports. The cxport-led stracegy, in addirion to gencrating resources, produced two other benefits. It altered the structure of production in rhe direction of Korea"s comparative advantage, and competing in the work sonomy forced Korca to continually pay attention to issues of human resources and productivity.

The word "mirale" has becurne something of a diche when desiriling the groweth and structural changes of Koreit's exports. In 1962 the value of Korea's exports was only $\$ 55$ million; then ame the export drive. In 1961 exports passed the $\$ 100$ million mark; in 1968, 3500 million; n 1970, \$1 billion; in 1977, \$10 hillion; in 1981, \$20 tillion; in $1985, \$ 30$ billion, and in 1988, $\$ 60$ billion. In 1960 Korea ranked 101 st itmong the world's exporters; coday it is the 12th biggest. The structural Change is no less impressive: according to Balassa 11984 ), in 1960 primary prexlucts accounted for 86 percent of merchandise exports and manufactures for 14 percent; by 1980 the shares had been completcly reversed-primary products acenunted for 10 percent and minufiactured goods for 90 percent of exports. The export surge enabled Korca to nun large surpluses on its current axcount since 1986 and to retire much of its substantial external dehr: in 1985, Korea was the fourth most highly indebed developing country (after Mexico, Brazil, and Argentina) with an external debe amounting to $\$ 47$ hillion: by 1988 that figure had dropped to $\$ 31$ billion, and as at percent of GDP or of expores had of course fallen even lowet than the corresponding rate in lys 5.

From the 1980 s to the early $199($ s), the Korean government had prepared to cope with an open etomestic marker by estahlishing a lomg-term plan for trade liberalization 
wnd tariff reduction. In the 1980 s import liberalization was accelerated, and the rate of import-liberalization rose to 95.4 percent ir 1988 . It is a result of the large-scale import liberalization in 1981 and 1982 and of the overall plan for import-libcralization after 1984 . Also, dhe Korcan government reformed policies for ariff reduction by infosing an equal tariff rate system. Since the 1997 ccononic crisis, the Korean government implemented a scries of policies for temoving or bringing down the non-tariff barricr on as great deal of items. '6 In 1994) the Korean government expanded import liberalization by lifting the ban, and by reducing the subsidy program. As a resule, the Korean tariff rate in 1999) could approash the level of the advanced countries as shown in Table 11.

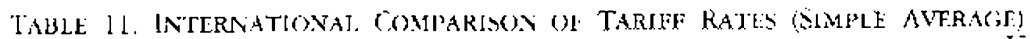

\begin{tabular}{|c|c|c|c|c|c|c|}
\hline \multirow[b]{3}{*}{ Total } & \multicolumn{4}{|c|}{ Korea } & \multirow{3}{*}{$\begin{array}{c}\text { U.S.A. } \\
1995 \\
4.9\end{array}$} & \multirow{3}{*}{$\begin{array}{l}\text { Japan } \\
\frac{1093}{7.0}\end{array}$} \\
\hline & 1988 & 1990 & 1992 & 1999 & & \\
\hline & 1.8 .1 & $1: i$ & 10.1 & 7.9 & & \\
\hline Agriculoure & $2 j .2$ & $19 \%$ & 18.5 & 16.6 & & 11.5 \\
\hline Manuficuturs: & 16.9 & $9:$ & 8.3 & 6.2 & & 22 \\
\hline
\end{tabular}

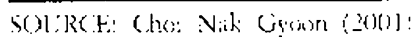

Kurean policy for foreisn diret investment had been father passive unt the 19)80s. 1 lowerer, accelerated libcralization began in the carly 190()s due to the Quinquenmial Plan for Foreign Investment I.iberalization (1993-1997). Consequenty, the level of foreign direce investment liberalirarion recently reached that of the OFCD countries. Also, according to an agreement with the IMF in 1997, foreign direct investment including financial capital and real estate has been fully permitreit except in politically sensitive scotors such as culture and national defense. Forcign exchatige and catpital flows hatd heen liberalizing gradually on 1940), however, liberalization was hurried along by the introduction of rle 'lescly: Flexible Exchange Rute System', in response (o) the economic istisis in 19y?

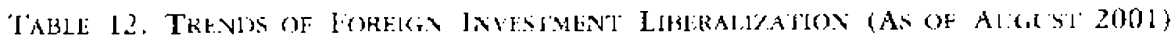
(Unit: Nunter of businesis)

\begin{tabular}{|c|c|c|c|c|c|c|c|c|c|}
\hline \multirow{2}{*}{ Industry } & \multicolumn{8}{|c|}{ Business Ofrented } & \multirow{2}{*}{$\begin{array}{c}\text { Business Restricted } \\
\text { still in } 2001\end{array}$} \\
\hline & 1994 & $1 \% 95$ & 1996 & $199 \%$ & 1998 & $19(x)$ & 20001 & $2(1011$ & \\
\hline Manudacrure & j & & ك: & 1 & 3 & 2 & & & (1) \\
\hline Scrvitic & $2 i$ & 42 & 30 & 16 & 20 & 3 & $\underline{2}$ & 2 & $2(22)$ \\
\hline $\begin{array}{l}\text { Aetioniture: } \\
\text { Feslers, Mine }\end{array}$ & 6 & 2 & . f & 10 & & & i & & $\therefore ?$ \\
\hline 'ist:t1] & ji & 1 & (1) & 23 & $\therefore ?$ & $\xi$ & 3 & $\therefore$ & $1(2 / 4)$ \\
\hline
\end{tabular}


'There sets of fiktors largedy explain Korca's export performance: first, the government's decision and implementation prexesses; second, the set of export incentives; and third, Korca's ability to ake tactical induantages of opporturnities offered by the international environment.

The effectiveness of the gewernment's decision and implenentarion procedures must begin with the government's commitment to the export drive. A thorough-going commitment to bousting exports began with President Park, whese strategy called for priority in coonomic development but with less economic reliance on the Inital Stanes. The pauciry of Korea's own resource belse muent that this development had to be based on industrialization (which in rurn would have to be import-intensive), and the arm of redeked detpendence on the lented States meant that this import-intensive industrialization woud have to $k$. financed through higher exports. It is not surprising: therefiore, to find Song (20)3) reporting that President Parkis favorite maxims we we "mation building through exports" and "exports first."

In the year following Presidene Park's setrute of power the Ministry of Commerce and Industry began serting export targets classified by commodiry and destination. fixporters who rearted their stipulated targets would recive favorable access to credit and other inducements; exporters who failed could swiftly sutfer from conomic and odher samerions. The Presietent himself alss chaircd a montbly meeting of exponers during which export targets were discussed and inpedimenrs on achiering those tarbets were removed. The participation of the President himsclf in these policy discussions and in the follow-up meecings alsu texplains the relatively small anmount of corruption ankl interference shown by che Kerean bureaucracy The World Bank (19)8) reporecel that exporting was identificed as the criterion of resource allocation, and the pertormance of all the actors - firms as well as burcalicrats - was monitored aganist this taryet. Mason et al, (1980) concurred, remarking that "although it

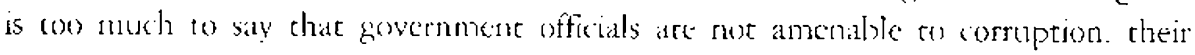
incervention rarely lads ro a slowing down of production or a failure a mect presitibed targets."

The gowernment and the business sector worked very closely. Jones and Il Sakongr (I9si) made it deat that the gevernment was the scrior partnet. However, over

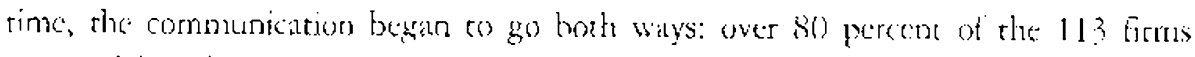
surveyed by Rhee ct al. (1984), sajd that their annual export target was their uwil estimate, which was sometimes adjusted by the government. The trade associations were regularly (monsuled to ascertain the incenrives needed to atcain targets. In the discussions. musth information was exchanged, and Rhee at al. reported that, "if siales in it region are not up to target, the Korcan anobassikdors there are recalled to find out what the problerns are and what can be ctone eo spur Korean sales." Onc could hatrdly ask tor a stronger governmene commitment os exporting.

Kurcal was also very inerovative resareding systems of expurt promotion. It conkl probably he satid withont tou much exaggeration that kortea used a variate of almost 
any incentive scheme for promoring exports that one can ahink of -Johnson (19)87) reports that 38 different "export policy tools" were used before 1976. The most important and most consistently used, however, were the exchange rate, the tariff-free access to imported inputs, and the provision of hank loans (often at subsidized interest rates) for working capital.

Petri (1990) states that since the 1960 s (except during the periud in which the heavy and chemical industries were being artificially stimulaced), the Korean government generally maintained the real value of the Won near the level needed for current account balance. This mean sharg) undertaking devaluarions from time to time, interspersed with fine tuningr adjustments. The realistic exchange rate evidently provided exporters with a substantial incentive. A study by the World Bank (1987) showed that export pertomance becween 1960 and 1975 was keenly responsive to thanges in the exchange rate: in a seven-year period when the real exchange rate: whas high (in 1965 purchasing power parity terms) the average annual growth rate of exports was 43.5 percent; in the seven-year period when it was low. the average growth rate was 16.0 percent.

'Ihe government alsu permited exporters untestricted, duty free access to imported injuts. As some ubservers - for example, Rhec et al. (198\%), Petri (1990)

noted, this created a freetrade regime for export activities. Producets of exports could thus purchase their inputs at world prices, and were not disadvantaged vis-a-vis their foreign competieurs. This was very important in Korea's case, because in vicw of the county's limited resource base, exports had to have a large import component - Steinbers $(1989)$ estimated it at around 40 percent for much of the poriod since 1960 . The preferential access to credit not buly facilitated the purchase of working invencories, bur the subsidy also made exports more profitable relative to domestic sales.

Finally, Korcat astutcly exploited some special tactors in the international environment. Because of doe historical links wirh Japan, Korea maineaincd a strong trading relationship with that country, whicle also served as the source of unuch of its techoulogy. In addition: Korea benetited from the relationship with the United States, in terms of US business practices, market requirements, and concracts for construction and transportation during the Viet Varn war. Korea was also fortunate that it began its export drive before other rapidly growing countries in Fast and South-East Asia started, and that it occured in as situation of gencrally increasing world trade. Contempurary newouness to the export drive are likely as hit protectienist batriers somer than stid Korea.

\section{Enharcement of Human Resources and Productivity through Education}

Kurea's ability eo compete in rhe internarional marker in increasingly sophisticated items meant that the country's human resource base had to be entranced. Investment 
in human resources was another important ingredient in Korea's success. The contribution of education to conomic growth has been the subjece of much research: for example, Blaug (1966), Schultz (1961), Denison (1962), and the referencts cited therein. The conclusions are that education improves productivity through the promotion of skills, incrcases innovarive ability through the advance of scientific and technical knowledge, and promores swift adapeation of technology that has been develuped elsewhere.

Educarion occupies a very special place in Koredn culcure. The Confucian ethic provalenc in the councry has stressed the value of education, often for its own sake, and the literarute is rite with storics of the sacrifices that tamilies make for the: education of their children. It is not surprising that une of the main achievements of the Kurean governmene during the 1950s was the exadication of illiteracy through at rapid expansion of educational institutions. lu 1915 the adult literacy rate was estimated at 22 percent. The 1970 population census measured it at 80 perecent, while estimates by the Wortd Bank in 1975 put it at 93 percent. Soxn thertafter, and wel] before most other developing countres, Korea aclieved 100 perente liferacy. The continued expansion of education, especially al secondary and tertiaty levels, provided avernes of upward secial mohility for ceen the lower midklle classes. It also endowed Korea with a snore prexhetive later force and enabled it to take advantage of export opportuniries.

In adedition to the cultural pressures, the rewards attiched to increascd education played an important part. For much of the period until the end of the 1980s, wage differentials laterely reflected education levels. (ho (Ig) p) shows that for rhis perioxl, workers witli less than a moddle school edacation carned lower wages dhan those who had attended high schoul who, in turn, eaned less than workers with a junior college education, who earned less than those holding a collegre or university deseree. In the 1990), there was some discission about the labor fores having become "overcducated," in the sense that declining returns to scale maly have sct in for education and that wage differertitiels less axcuratcly reflected differences in education.

In a careful study of the concribution of education to Kurtan growth in the period $1960-74$ (the years of the "takeoff"). Kim (1980) esrimated a lower bound for the contriburion of education. He calculated that over this period as a whole. education contribured 8.4 percentatge points to the growets rarc. The biggese contribution came in 1960-60, when its contribution wäs estinated at nearly 15 percent. Kim judged that the actual contribution of education thoughout the period under

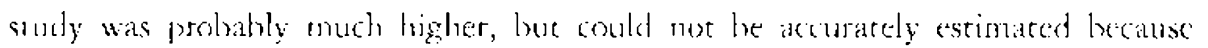
it could noc be separated from the contributiun of oome of the orber sources of grouveh.

However, this does not man that there wals a straightfonward correlacion between Erowth of celucation and the contriburion of productivity to coconomic growello. In fact, the rise in productivity contributed less than did the increase in factor inpurs. 
This apparently resulted from heavy investment in capical-intensive industries in the late 1970s. The overall conclusion about the contribution of tutal factor productivity to economic growth in Korea is that it was at very important but not the dominimt factor (sce Table ]3).

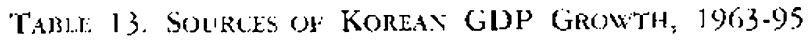

\begin{tabular}{|c|c|c|c|}
\hline & $1963-73$ & $1973-86$ & $1979-95$ \\
\hline Real GNP growth rate & 9.5 & 7.8 & 8.0 \\
\hline 1. Contribution of inputs & 5.4 & 4.1 & $+t . t$ \\
\hline Latwo: & $3 \%$ & 2.2 & 2.6 \\
\hline Capital & 2.2 & ..9 & 1.8 \\
\hline 2. Total factor productivity & 4.1 & 3.7 & 3.6 \\
\hline Advalioes in knowledgo & 1.4 & 1.6 & $1 . \overline{7}$ \\
\hline Improves! tesource allocation & $1.1\}$ & 0.6 & 0.1 \\
\hline Eiononies of slitk & $! 7$ & 1.5 & 1.5 \\
\hline
\end{tabular}

SOLRCE: Sung (ZnO3)

\section{Attention to Agricultural Development and Kural Hoguity}

The fourth important imperus to poverty alleveation, particularly in the rural areas, cance from the land reiorm. Soudies in several countrics have shown that a major cause of income incqualities in rural areas is the distribution of ownership of rural assets, primcipally agricultural land. Korea was able to undertake a thoroughgoing land redistribution betwecen 1945 and 1950 for rather special teasons. During their occupation of Korta (1910-45), the Japanese authoritics confiscaced much of the country's arable lind, and at the end of the period about 40 percent of agricultural land was in their hands. Witl the defeat of Jaysan in World War II and the cond of the octupation, this land became available fot discribution. Moreover, as Mason et al. (I)SO() express it, "Korean landlords ... also carried the taint of collaboration with the Jatranese, at least in the eyes of most of their countrymen, and these larkllords, as a result, were not in a politically strong pusition." Thus these was lictle need to distribute the former Japancese-held land to existing Korcan landownces, and the land that recovered from the lapanese owners was in the main allotted to the landless or to those with very uneconomic holdings.

The redistriburion of land previously owned by the Japaneste was supplemented by a land reform that the grovernment put through in 1949. Limiting luskdings to approximately 3 lectares. The owners of the land that was thus obtained were offered inly minimal compessation, effectively equal to only 1.5 times the average annual product of the land. While thare probably was some cvasion of these limits by illegral registration of land under the names of different family nembers, the setorm was 
an owcrwhelming success. Ban et al. (1480) reported that tenancy, which had been 18.9 percent in 1945, fell to 5.2 percent in 1964, while ownership jumped from 13.8 percent to 71.6 percent berween the two ycars. Stembers (1982) commented that, "If income is more eyually distributed toxtay in Korea than in mary developing sexiecies, the primary reason is to be found in these latud reforms."

In the eurly years following the scond World War, the rural areas in Korea sulfered from acues poverty. A survey tevealed that in the period just before the harvest, oumerous farmers had to rely on roots and hark in order to survive. The budgets of many fars houscholds wete continually in deficit, leading ro severe problems of rural indeloedness at high fares of interest.

The strategy of rippid GDP growth also induded the agricultural sector, especially: from the late 19605 , ane: soon changed the picture in rural areas. The main policy change was to sharply radse prices in 1969 for agriculeural produse (particularly rice and basley) retative to the prices of agricultural inputs. Moreover, since the

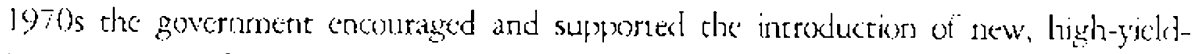
ing, vartetics of sice (the "green revolution"), which incteased rice yiekds per acre by almost 50 prercent. The government also stepped up investment in rural development, a particulat insratce of which was the lanching of the Saemaul Lindong (Now Community Movenent) in 1971. According to Song (2003), in the mict-1970) almost 10 percent of totil national investment was allocated antually to rural areas through the Saemdul Undong. This, of course, was in addition to private investment in agriculture and to public: investruent in agriculcural and rural infrastructures.

The resulting improvernent in rusal incomes was impressive. For cxample, farm bouschold income increased from $\$ 413$ in 1965 to $\$ 15.391$ in 1990 , rising further to $\$ 25,280$ in 199 . However, since the growth strategy latid primary emphasis on industrialization and arbanization (che population living in urban areas increased from 28 percent in 1960 co 78.5 percent in 1995), is is not surprising that urban inconcs ruse more rapidly, and that accorcling to Park the per capira incornc of Seovil was 1.8 eimes lighter than that of rural arcas, white average income it other cities was higher than raral income, buth per houschold and per capita, by a factor of 1.5 . The inplication of these developnents, as Park poines out, is that the ralative income of farm houscholds comprased to urban wage earner housclolds has worsened since the $196(5$, so that by 1430 farm hessehold incume was only about 70 percent of rhate of urban wage worter househeld income. However, while this might indicate al worsening of relative powerty between rusid and urbar households, it dos not carry the same implication regarding aboluce poverty. Morcuere, it appeas that the discsilution of incomes within urbius arcas is more skeved, so that a larger proportion of housetalds fall halow the puserty line.

'able 1.1 shows changes in the contribution of agriculture and a comprariosn of rural and urban houscloold incomes. 


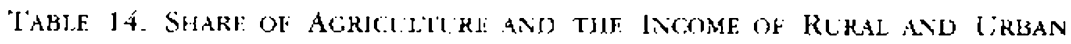
HOTISFHOI.IS, $1955-2000$

\begin{tabular}{|c|c|c|c|c|c|}
\hline & Share of agriculture & Share of Farn Population & Household & lncome (cho & usand $\mathrm{m}(\mathrm{m})$ \\
\hline & in GDP (\%) & in rotal $(? ;)$ & Rural (A) & Irban (B) & Rate (AB) \\
\hline 1935 & 43.9 & 61.9 & lid & rist & nit \\
\hline $1 \times 60$ & 36.5 & 583 & па & $n: 2$ & $11 \mathrm{a}$ \\
\hline 1963 & 376 & 55.8 & $112 ;$ & 112.6 & 93.7 \\
\hline 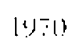 & $2 / 3.8$ & 15.9 & 255.8 & $381 . ?$ & $6 \div 1$ \\
\hline $19: 5$ & 21. & 13.2 & 8725 & 8543 & 101.6 \\
\hline $10 \times 3$ & $1 \therefore 1$ & 289 & $261) 3.1$ & 2804.13 & 95.4 \\
\hline $19 \times 5$ & 13.3 & 21.1 & 57362 & 60.66 .4 & (2).1) \\
\hline $100(0)$ & 8.7 & 15.5 & 1103 & 11319 & 97 \\
\hline 1045 & 6.6 & 10.8 & 20315.8 & 20415.6 & 945 \\
\hline $2(x) 1)$ & 46 & $8 . ?$ & $23(1) 72.1$ & 28642.8 & 80.6 \\
\hline
\end{tabular}

\section{Expansion of Employment}

The fifth important factor in Korca's ability to allevide poverty rapidly was the exparision of enploymenc. It has been said that the expansion of education improves the supply side of the labor equation; unless the demand side expands simultaneously, the result will only be a large number of educared uncmployed who will remain frustrated. It is clear that Kurta was able to do both: the strategy of high growyth based on exports created the demand, white the push for more education and training improved the supply. Table 15 show's developments in the unempluyment rate during $1963-2000$.

TABI.E 15. DNHPEOYMFNT RiTE, 1963-2000

\begin{tabular}{|c|c|c|c|}
\hline & \multicolumn{3}{|c|}{ Lnemployment Rate (percent) } \\
\hline & Total & Male & Firiode \\
\hline 1963 & S..' & - & . \\
\hline $16(3)$ & $\therefore \dot{4}$ & - & \\
\hline 1970 & i.s & - & . \\
\hline $19: 5$ & $4, !$ & & - \\
\hline 1980 & 5.2 & 6.2 & 9.5 \\
\hline 195 & $\{.13$ & $5 .(3)$ & 2.1 \\
\hline $19 \%$ & 3.4 & 2.9 & 1.8 \\
\hline 1945 & $\therefore .1$ & 23 & $1 . ?$ \\
\hline 20001 & i.] & 1.? & 3.3 \\
\hline
\end{tabular}

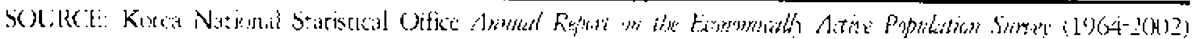


Enemployment dropped from 8.2 percent of the labor force in 196.5 to only 2.1 petcent in 1995. In fact, it is likely that the figures for earlier years somewhat understate the accual rate of unemployment because of some familiat probletns, such as the "discouraged worker" effect. The decline was fairly steady, although there were one or two hlips. In particular, the decline was arrested in 1980, when the Korcan conomy was hit by the second oil price increase. However, the expansion of the GDP and the conseguent increase in demand for labor rapictly resumed. The expansion in employmene was a major factor in increasing incomes and reducing poverty.

\section{Strengthening the Apparatus for Implementation and Coordination}

'The hest-laid plans and the best-meaning policics ase noc of much use if they are nor implemented cffectively. The sixth important factor behind Korea's success in poverty reducrion was the country's capacity to implancent plans and projects expeditiously and within budgeted costs. This ability derived from the structure of economic decision-making and the quality of the atminiserative services that carried sut the policies.

Although Korean planning had begun in the 1950 s, it really beame ctfective only after the actession to power of P'resident Park Chung Her. In 1961, Park establisherd the Economic Planning Bourd (EPB) to deal with economic planing, national budgering, foreign capital management, and statistics. In 1963, the Minister in charge of the EPB was designated Deputy Prime Minister and given the overall responsibility for all conomic miniseries. The budget was also put under the EPB. Whilc economic policy proposals were gencrally initiated by the miniscries concerned with the areas on which the policics chictly inpacted, the proposials were reviewed by other economic ministries that might have an interest in these matters. The coordination of economic policies was theretore given a rusere formal structure. "Ihe ecoumic ministers met regularly in the Economic Ministurs Consultacion Mcecing, which formalized policy propusals to be submitted to the Cabinet. A similar mexting of coonomic vice mimisters was also held: this group desale with more technical issues and then submitted their proposals is to the ministers' neeting. 'The authuricies also creaced specialized research institutions that supported the coonomic and other ministries; the Korca Development Institute (KI)I) under the EPB is perlaps the hest-known of such insticutions.

"wo other institutions that played a major role in economic development were the oftice of Narional Tax Adrninistracion and the Office of Labor Affitis. The former was important in mobilizing sufficient resources to finance the development of the public scetor. According to a doxument. President Park would himsdf check progress on mecting tax collection targets on a daily basis. "lhe. Office of Labor Aftairs was important beciuse it was resporisithle for maintaining labor peace so that Korca coukt continue to enjoy cust compecitiveness in exports. The office not only enforced labor standards, but also proterted workers' rights in such ateas as industrial disablement and organized vocationid traming progeams to holp workers accuire the skills neteded 
for indesstrial development.

Fconomic policies, formulated in this manner, were then eftectively implemented by a well-trained civil scrvice. President Park's regime undertonk a major retorm of the civil service, both by the purging the buteacucracy and by reforming recrument procedures. 'The higher civil service in Korea has traditionally been an cnomously prestiguus professiun. and cutrance into it remains fiercely competitive. 'lhus, Cheng at al. (1999) reported that in 1949) there were 100 exam-takeri for every successtul applicant. These tigures rese steadily, and in 1956 only one out of 200 applicants managed to corer the service, while in 1957 there were 315 applicants for every successful entrant. 'The civil service was also made more protessional by reducingr the number of lateral entrants, i.c. persons whe did not cone though the nom entry exanjimations, and the number of internal promorions, largely governed by merit, wete also drastially increased. For example, Cheng et al. (1999) quote figures to the effect that under the iktministration of President Rhese only it perecent of higher civil servanes entered the bureaucracy through norit-based cximinations, hut under President Park more than 20 percent contered thire waty: moreover, the number of internal promotions, giverned largely by merit, also increased at the top sanks. It

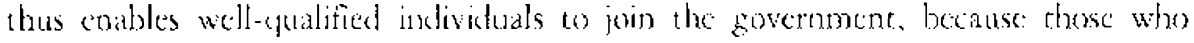
pass the high civil scruce exanminarions can stant an a higher grade, with larger responsibilitics and in corresponding higher income.

However, Kontan civil scronts were not well rewarded in terms of salaries compared with the private sector. IIntil the mid-1990), the average monthly salary of civil scrvants was ondy about (6) percent of what an individhal with equivalent celucation

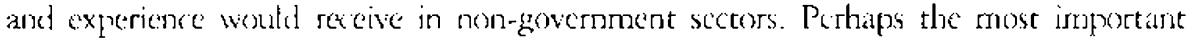
incentive provisled to civil servants was the social respect, which was imbedded in Korea s culture. Such non material taktors have to be taken into aceount in judging

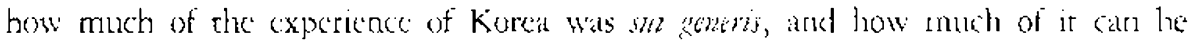
regarkal as generic and the lessons from which can be translated to other countries.

An important responsibility assigned to the liPB and some other agrencics was that of actaining consensus on the government's plans and policies. In fact, three

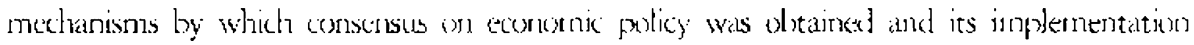
monirored. The first was al monthly comomic bricting held at the EPB at which the President, all minisecrs, other senisr government findurs, and the heacts of bign business and fuancial urgangations attended. The scond was the quarterly mectings of the Trakte Promurion Conference. Ithis mecting was atended by the President. ministers, high government oftecials, as well as the heads of almost all the latge crading firms in the country. The Ministry of Trade and Industry would submit reports on the progress cowards achicving export angets and the problems and difficultics that industrics fiaced in metting their export gads. 'Ilke. President was himsclt involved in offering comments, sugerestions. and orders on handling these problems. The third

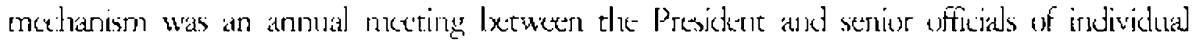

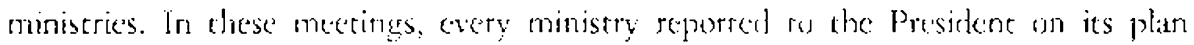


of activities for the current year as well as its perfornance oper the previous one. The presiden shen commented on the successes and failures, on the plans for the coming year, and authorized the ministry to proced with the plau or to make adjustments. 'Ihe importance of these meetings lay in the clarity that they imparted to the Ministry concerning the President's views on the direction of policy for the coming year, and on the uncquivocal nature of the President's involvcment in economic management.

$A$ feature of sovermonene interention in the planniog and managenent of the economy has becn its pragnatism. A particularly clear example of this flexibility was seen in the transtormation of the role of planning and of the Economic Planning Board as the conomy became increasingly complex. The formulation of the Sixth Five-year Plan was undertaken with even greater participation of the private sector; in fact, alnost half the membership of the committees that prepared the initiad propexsals for the plan was drawn from non-govemment sources. Thereafer, the role of the EPB moved increasingly towards analysis, courdination, and advice until the Burcau was sulswimed under the Ministry of Finance. The management of the cconomy is now increasingly indirect and conducted largely through fiscal and monctary signals, rather than through direct orders. The authoricics, therefore, have shown that they are propared to constantly adapt the administrative apparatus to the necals of the ecomony, and thus to ensure the comtinued efficalcy of the institution.

\section{CONCLIDING REMARKS}

This case study analyzed how Korea achieved rapid economic growtl wath increasing equity and poverty alleviation. Korea's achevements are particularly ineressive considering chat less than 25 percent of the country is suitable for agricultural or orher ecotomic activities and that Korea pussesses lew natural resources. Morcover, the country had to tecover from a devastating ciril war that destroyed most of its infrasructure. Koreis sucess was due almost encirsly to adopting the right economic policies, taking atrantage of opportunities, and maintinining at disciplined work cthic.

In Kurea, dramatic poverty reduction during such a short perioxl was possible thanks to the rapid increase of mean income by equally rapid conomic growth. Korcan GDP per capita increased 110 times and absolute poverty rate decrased from 18.3 percent to 9.8 percent between 1961 and 2001 . Of course, increase of income does nor necessibridy sesule in poverty alleviation as cvidenced in many developing comntries. Howerer, it is true to say in the Korcan case that the most effective measure in reduction of the absolute powerty level has been to make the natiunal conomic pie bigner. It was called gronelotiest-distribution later principle. which broughe about counonic success by overconing a sevete blostage of natural colownents.

Also, income augmentation by industrialization is more effective to alleviate provesty,

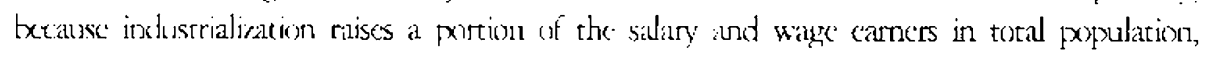
and then it makes it possible to expand welfare system on the basis of the salary 
and wage eurness' contribution under the social solidarity. 'L'he expansion of uelfare reduces again the proverty level. 'Therefore, sound GOP groweth is a locomotive engine for poverty reduction.

The Korear government prioritized certiin development-led industries in order to accelerate economic groweh. It was called "imbalaned development strategy" and asscssed as being more cffective than "balanced development strategy" within the limited budget for economic development. Although incone inequality becane as gravated during economic development, the size of the pie was drastically increased. The incone level of midelle and low inconte households increased to such an extent that much income inequality could be tolerated. It an be said that in Korea, rapid economic growth raised welfare levels during the period berween the 1960 s to the 19yos cuen as incone inequality worsened.

Aficr a long period of rapid economic growth. Kurta rar intu serious economic difficulties in late $19 y 7$. The povery rates rose sharply from 7.67 percent in 19y7 to 14.28 percent in 1998 . The Kortan government undertsol various anti-porecty progranas designed to ease the impact of mass lay-offs. The government implemented a new public assistance program (che National Basic Livelithex becurity) and expanded the coverage of social insurance. In addition, human resource development programs were introblucal that entranced the access of the vulneralle class to the lator market by laying stress on labot welfare, taking measures to protect irregular employecs: and extending the application of the minimum wage system to all industries. Ithe intoduction of the new public assistance program trijled the number of livelituoud payment benesiciaries from 5.10 .000 in 1909 to 1.53 million in 2001 . Expansion of social security coverage broughe atoun drastic reduction of the group excluded from the social security schemes. As a result, anyone who has an income could be covered by the Dational Pension scheme. ous can get medical service throughour the year, and all regular workers in all rypes of workplaces could lo covered by employment insurance. Thanks to these cfforrs of the grovernment, the poverty rates decreascd since 1999. However, the peverey rate in 2001 wias still highter than that in the years prior to the cconomic crisis, because it is assessed that the grovernment's efforts to reduce poverty level during the period of economii erisis had nor beco sufficient to overcune the problem of excluding some from their coverage and that the difficulty shoukl be dealt with on multiple fronts.

This study has led us to several tentative but useful lessoris to be applied to other developing countrics. First, it is necessary to establish a clear objective of aleselepment and the commitment of uuthorities is a prerequisite. Korea had wo represcntative motos "cscape from the vicious circke of powerty" and "Inoternizing the fatherland". The key lactor in Korea's success was the conmitment of authoritices at the highest level to coonomic development, and the strong perception that policies that had been announced weuld. in fact, be implemented. A lesson that other countries can Iearu from Koreats experience is the imporrance of estalolishing the grovernment's credibility in the implementation of announced policies. 
Second, a perceptive selection of represcntarive locomotive engines for rapid comomic growth and properly elesigned management are necessary. The fast growth of Korea was fuclled by a very rapid expansion of exports. Three sets uf factors largely explain Korea's export pertornsates: first, the governmen's decision and impletnentation proccsses: second, the set of export incentives, and third, abilicy to rake ractical advantages af opportunities offered by the international environment.

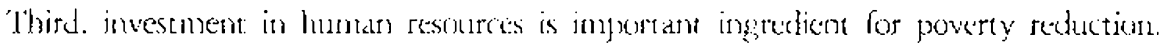

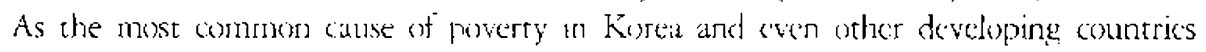
is the lack of working capariey: pun physical contirion or lack of education, working experience and skills, education and training are key tators to reduce the porr.

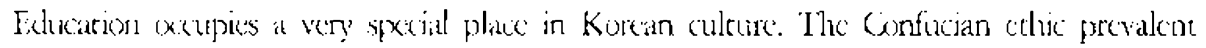
in the counry has stressed the value of cducation, otten for its own sake, and the

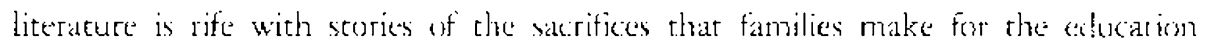
of their chiddren. One of the main achicvemetses of the Kescan gevernmene during the 1950s was the exadication of literacy through a rapid expansion of educational

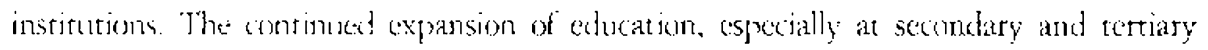

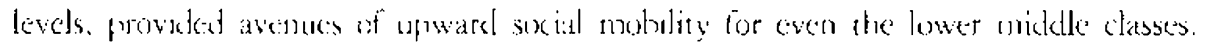
Also, nationwide nerwork for jol traning had provided the concernest people with an easy access and oppastunities to build their capacity and especially training programs offered in the army were assessed wo be particularly effective.

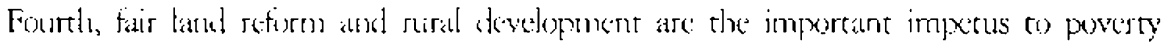
alleviation. Seudies in several countries have shown that a major cause of income incogualiticy on rural areats is the distribution of ownership of rusal alssets, principally

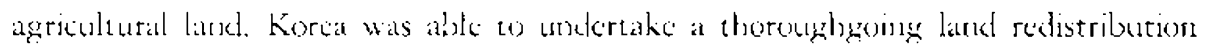
beeween 1945 and 1950. This land retorm would be the primaty reason of the more expally disrributed income in Korea than in many developing secieties. The government also seeped up insestment in sural developenerne, a particular inscance of which was the lambhing of the Stematul lindong (New Community Movement! in $197 \mathrm{l}$. In the mid- 1970 s atnust 10 percent of tutal natjunal investnente was allocuted annually 51) rural areats through the Saconatul Condonge This, of colurse, was in addicion to

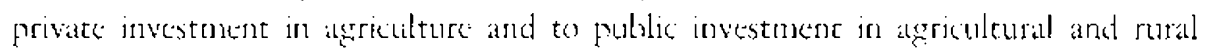
infrastsucture.

Fifth, job creation and expansion of employucht are the important factors to alleviate poverty. It has been said that the expansion of ciducation improves the supply side of the labor equation: unless the demand side expands simultancously, the result will soly be a large number of cefacated uncopployed who will romain frustrated.

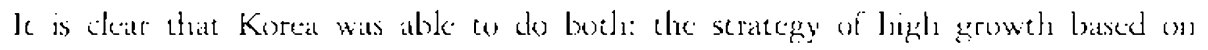
expores created the demand, while ele pust for more aduation and traming improved the supply. Eneomployment stropled trom 8.? percent of the labor torec its 1963

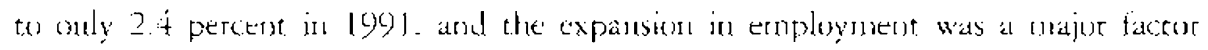
in increasing incomes and scalusing poseres.

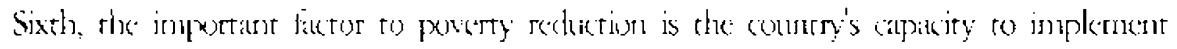


plans and projects experlitiously within budgeted costs. This ability could derive from the scrucruse of counomic decision-making and the quality of the administrative services that carry out the policies. Bconomic pulicies should be effectively implemented by a well-trajted civil service. The higher civil service in Korea has traditionally been an enurmensly prestigious profession, though Kurean civil servants were not well rewarded in terms of salaries compared with the private sector. Perhips the most important incentive provided to civil servants was the soxial respect, which was imbedded in Koreas culture. Such non-material factors have to be taken into account in judging how much of the experience of Korca was juf gemeris, and how much of it can be regarded as generic and the kessuns from which can be translated to other countries.

\section{REFERENCES}

Anand, Sudhit. 1997. The Lefinition and Measurement of Poverty. In Weassmement Of lncquality and Porty; cl. 5. Subramanian. Delhi: Oxford University Press. Balassa, Bcla. 1984. Foreign 'Trade and the Development of Korea. In Foreign Trads'

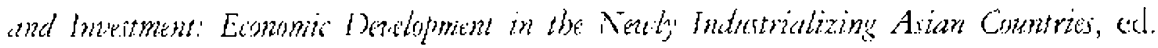
Walter Galcoson. Madison, Wisconsin: Iniversity of Wisconsin Press.

Ban. Sung Hwan, Pal Yong Moum, and Dwighe H. Perkins. 1980. Rural Development. Canbridge, Mass.: Harvard University Press.

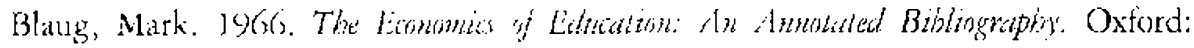
Oxfurd University Press.

Cheng, 'Jun.Jen, Srephan Hagsard, and David Kangr. Iyoy). Institucions and Growth

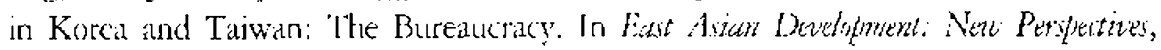
ed. Yilnaz Akyüz. London: Frank Cass.

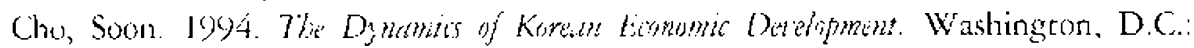
Insticute for International Econumics.

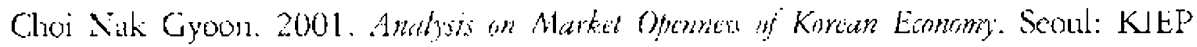
(in Korean).

Cole. David C. and Y. C. Park. 1983. Finumial Development in Korter. 1945-1078. Cambridere, Mass: llanvard Lniversity Press.

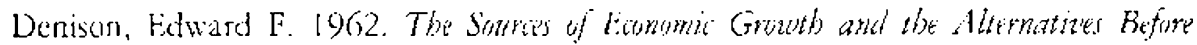
Ui. New York: Commitece for Enononic Developruent.

IFiclus Gary 5. 2001 . Distribition and Developntent. Cambridge, Mass.: MIT Press.

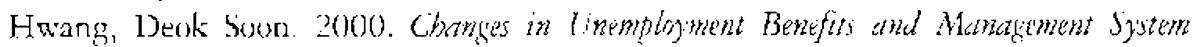

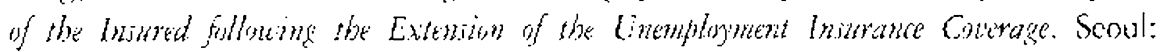
Korrea Labur Inscitues (in Korcan).

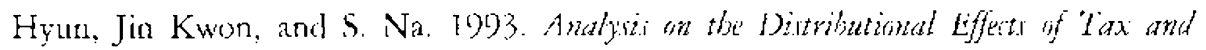
Public Ascistance Prificis. Seoul: Korea Insticute of Public Finance.

Johnson, Chalners. 1987. Political Institutions and Ficonomic Performance: 'The' Government-Business Relationship in Japan, South Korea, and Tawan. In whe 


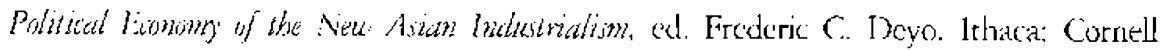
University Press.

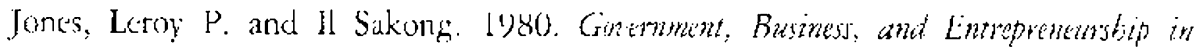

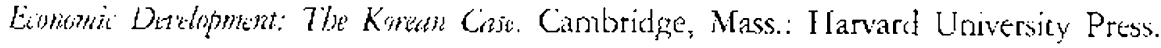
Kim, Ycon-Wyung. 1997. Application Proccdute of Korea Social Insurance and

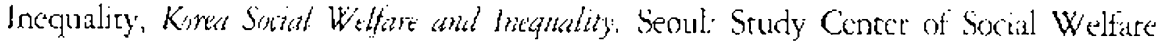
(iis Korcan).

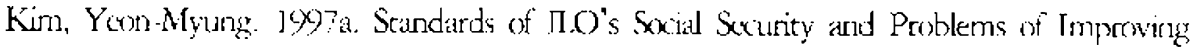

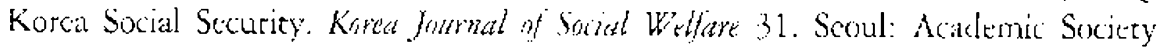
of Social Welfare (in Korean).

Kim. Y'ung-Bong. 1980. Education and Ecomonic: Crrmeth. In Homan Rromistes and

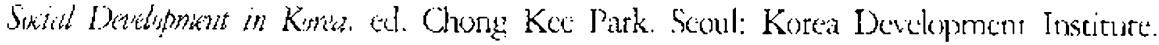
Krause Lawrence B. Iy)7. Ihe Political Econony of Sourh Korea: Filly Years of

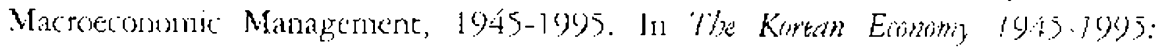

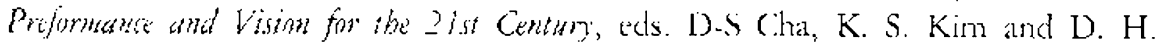
Perkins. Seoul: Korea Development Institute.

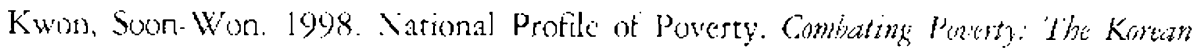
Exprenerue. Sculd: UNDP.

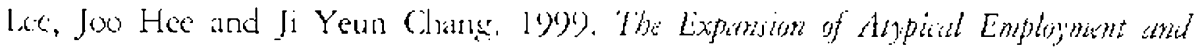
pulin Agendi. Seonl: Korea labor Insticute.

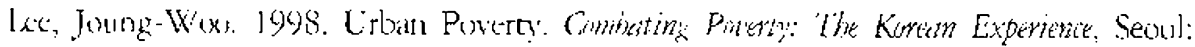
LNDP.

Math. J. S. 2(10). The Impact of Clobalization on Income Distribution: the Koreat

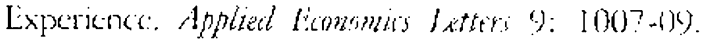

Mason, Edward S., Mahn Je Kinn, Dwigsht 11. Perkins, Kwang Suk Kinn, and David

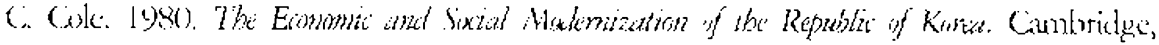
Mass.: Ilarvard Lojuersiry Press.

Micim. Nixl F., Donald R. Snodgrass, Yunge Bung Kim, Shin-lizk Kim, and Quee-Young Kim. 1980. Eduation and Detelopment in Korct. Cimbridge, Mass: Harrard University Press.

Ministry of Hetalth and Social Affairs. 1991. Yeartome of Health and Serial Shativitio. Arrumal.

Ministry of Healeh and Weliarce 1963-2001. White Peper.

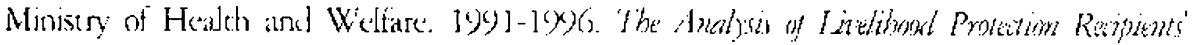
Stalur (in Korcan).

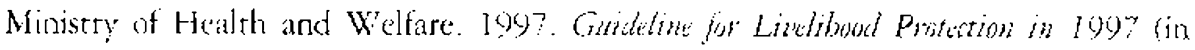
Kortari).

Winistry of Ialmor. 1990-2001. While Pcifer.

Nitional Burcau of Statistics, Economic Planning Board, Republic of Korea 1987. Amunt Regun on The Family: Inome and Expenditure Strme. Seoul.

National Committed for Survey Development of the Selt employed Income. 1909.

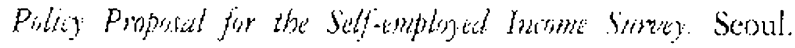


Narional Statistical OHfice. 1965-1996. Anmal Repgnt on Lrban Howshold Expenditur (in Kurcani).

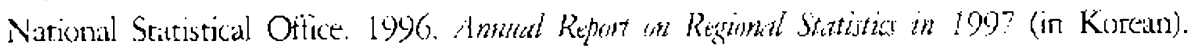
Satronal Statistical Office. 1997. 1995 life Tabier for Koret (in Korcan).

National Statistical Office. 1996-1997. Swat Instators in Korda (in Kureari).

National 'I ax Service. 2000. Amomesnent of Madifying a Value Adald Taxatim Syotem. Scoul.

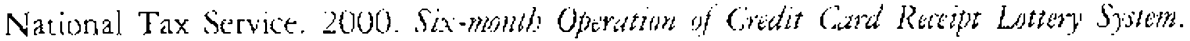
Souts.

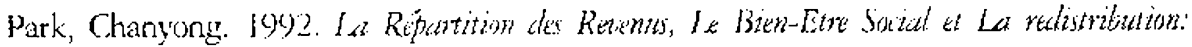

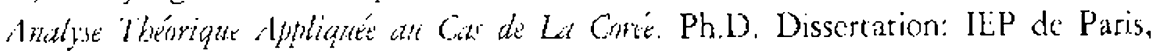
Paris 19y?

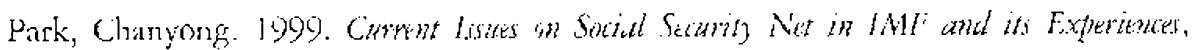
Policy Paper. Seoul: Korea Institute for Healels and Social Affairs (in Korean). Park, Chanyong. 2003. Analysis on Redistributive Effect of l'ransfer Income and

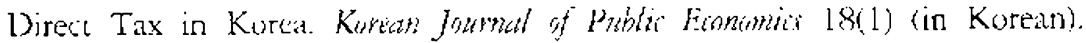

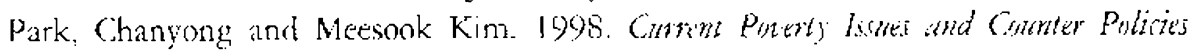
in Kowi. Scuul: KJIHASA-LNDI.

Park. Chanyong and G. Kin. 2000. Poverty Measuremenc by Characteristirs of

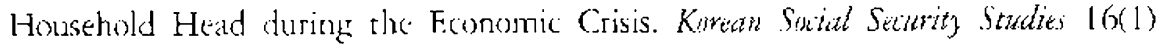
(is) Korcant.

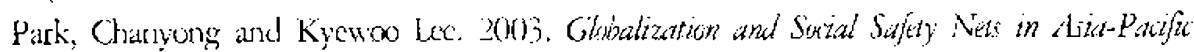
Regign. KHHASA: APEC SSN C.BN and Ministry of Healeh and Welfare.

Park, Chanyong and T. Kim. 2003. Change in Poverty After the 199: Economic (irisis, (Mirnco)

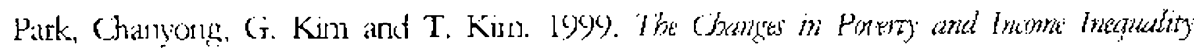

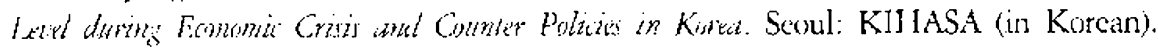

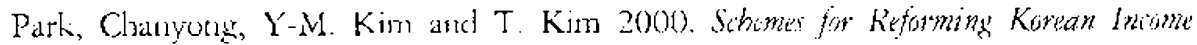

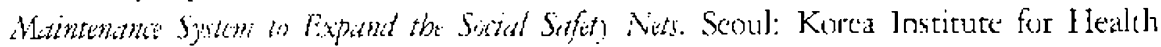
and Social Aifairs (un Korcan).

Park, Chanyong, K. I.ce and H. I.ce. 2601. APECs Measung for Strengthening Snizul Safety Nets in the Aliat-Pathi Regron. Sooul: Ministry of I Iealth and Welfare of Korea and KIHASA.

Park, Chung, I lee. 1963. The Countm; the Renisutim ant l. Secul: Hollym Corporation. Petri, Peter A. 1990). Kurcan Trade as an Outlier: An Ecomomic Anatomy. In Kontan

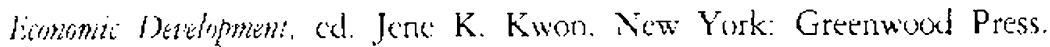

Presidential Committe for Quality of Life. 1999. Df Welfarism. Scoul: Office of the President of Korei.

Rhere, Yune Whee, Bruce Ross-Larson, and Garry Pursell. 1981. Karedis Grmpetztat

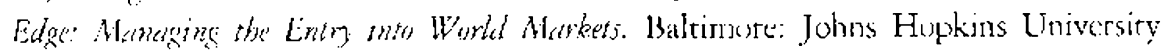
Press.

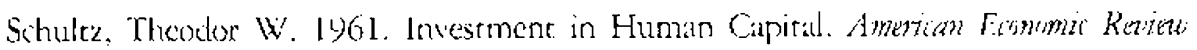


( $\mathrm{N} ; \mathrm{ar}(\mathrm{h})$.

Song, Byung-Nak. 2003. The Rise of the Kurath Fiomme. Ird ed. Hong Kong: Oxford Iniversity: Press.

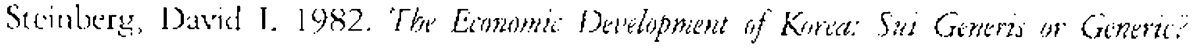
Washingtor. 1).C.: LSAID.

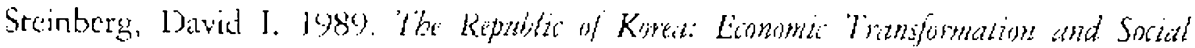
Chome: Bomliter, Colorado: Westuitw Press.

Sub, Sang Mok. 1985. Exononic (Growth and Changes in Income Discribution: The Korean Case. KDI Working Paper 8508.

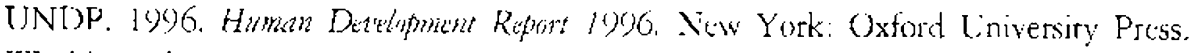
Workd Bank. 1487. Kinta: Mamaing the Indiatrial Timnition. 2 vols. Washington. D.C.: World Bank.

\section{FNDNOTES}

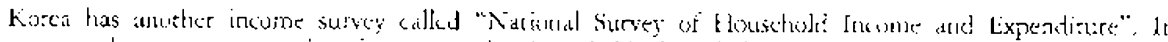

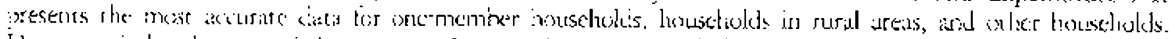

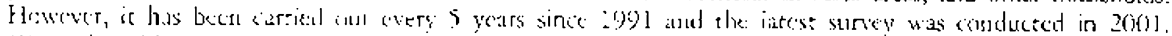

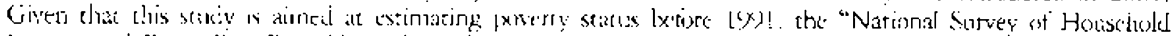

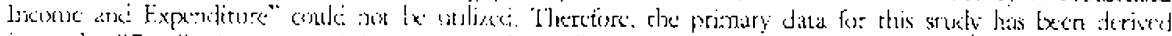

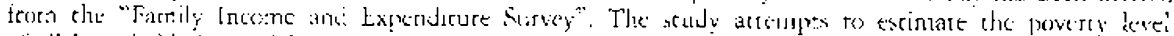

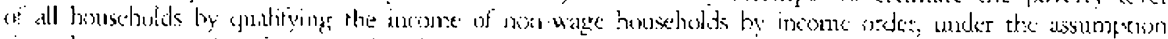

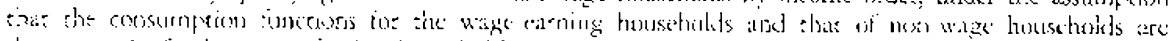

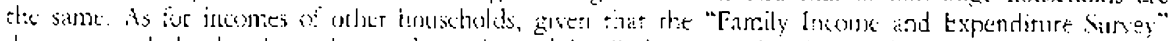

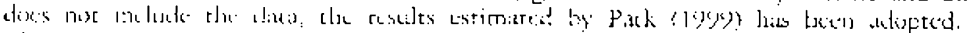

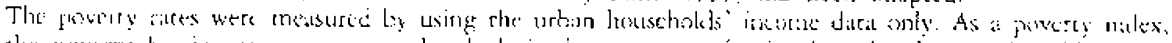

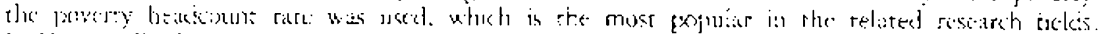

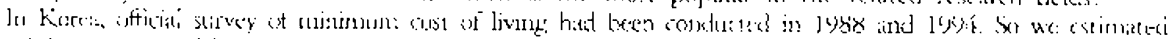

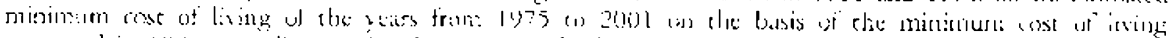

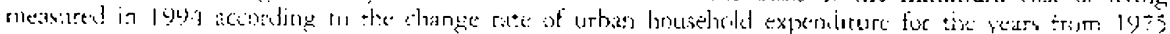

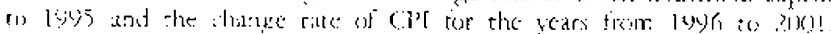

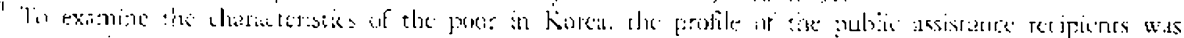
revertick.

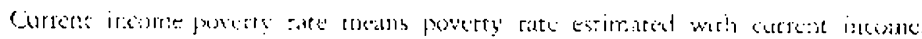

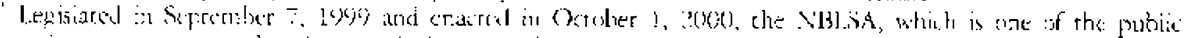

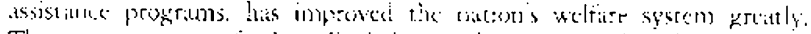

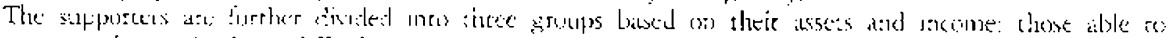

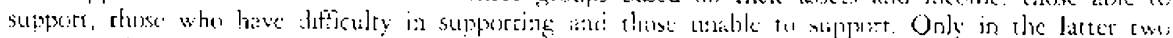

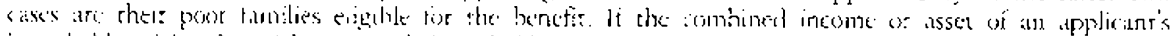

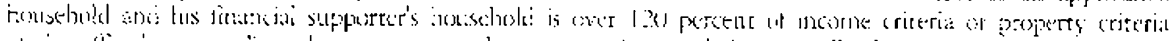

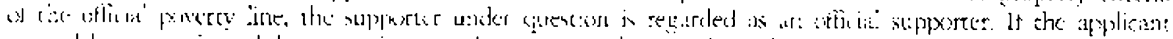

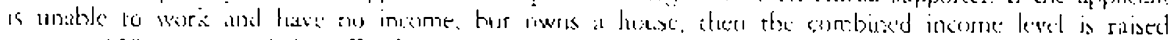

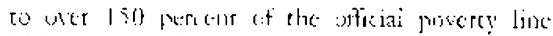

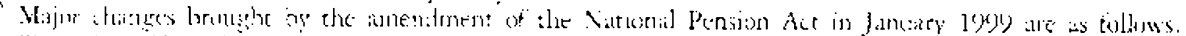

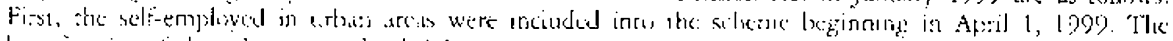

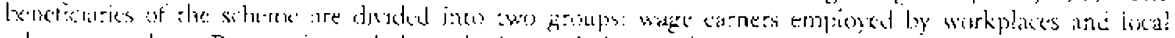

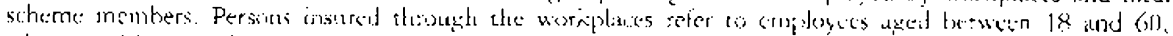

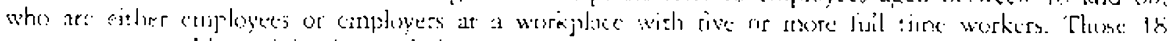

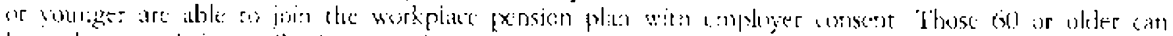

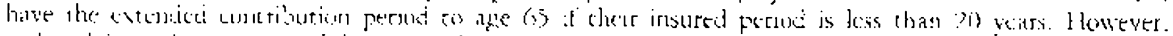

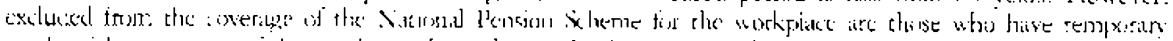

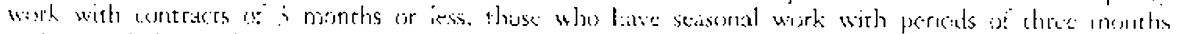

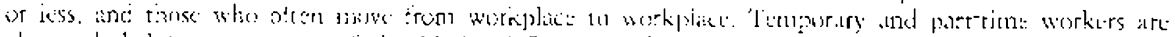

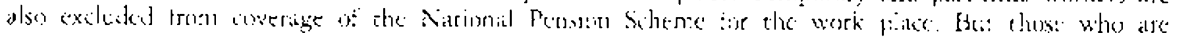




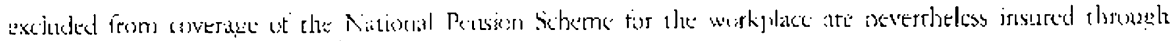
the Lexal sitheme if Niatsusal Pension.

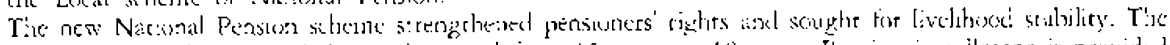

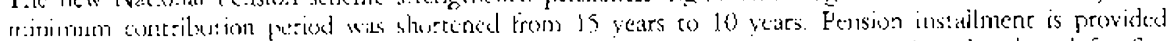

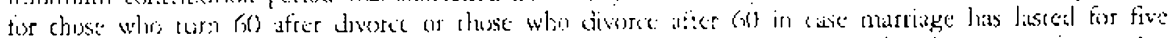

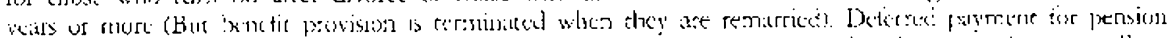

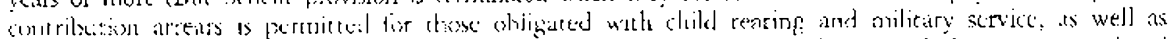

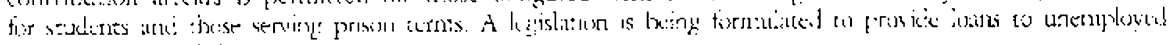
$f_{1}:$ brelihused sabilaty

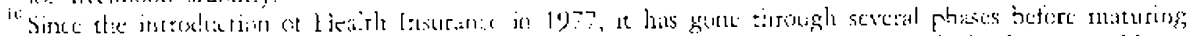

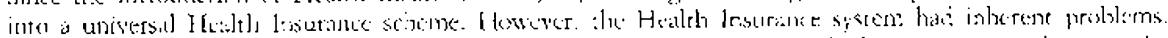

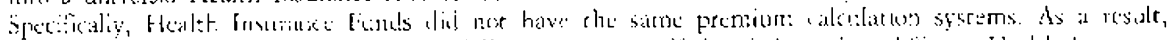

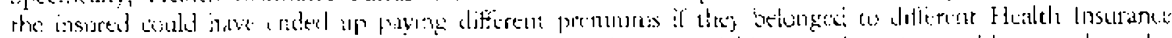

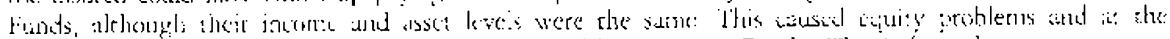

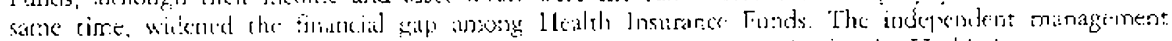

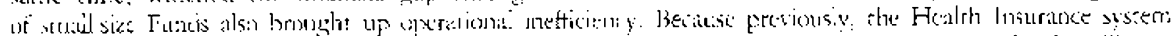

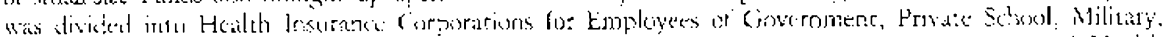

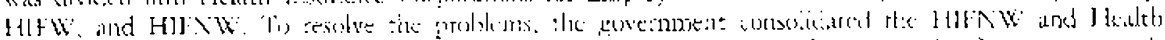

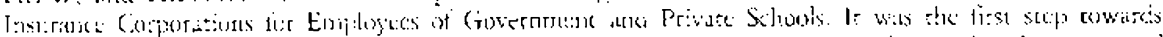

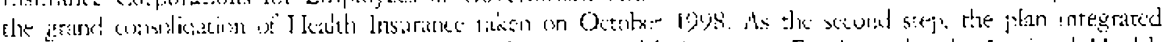

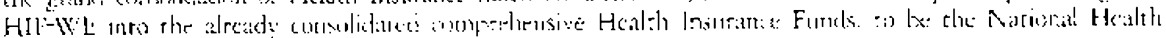

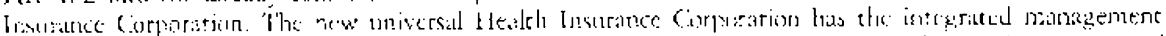

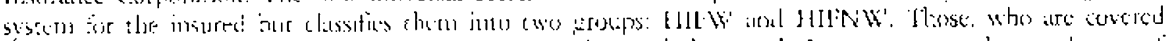

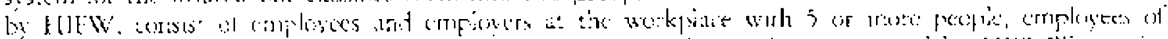

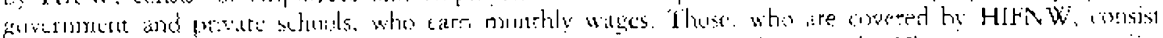

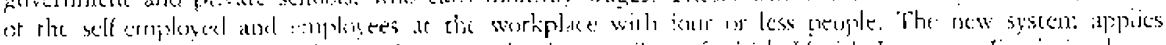

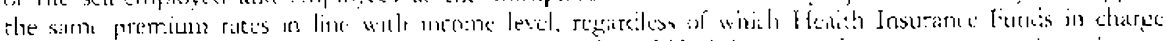
:

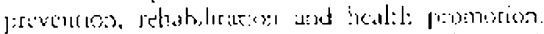

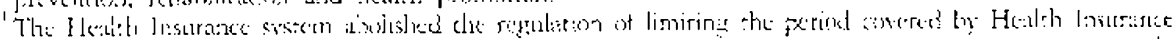

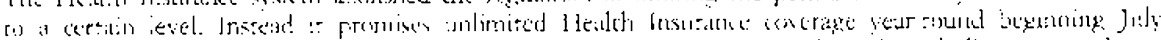

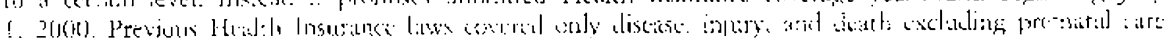

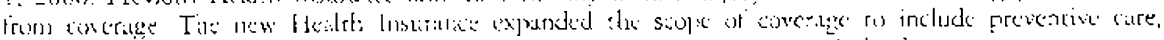

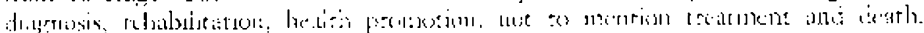

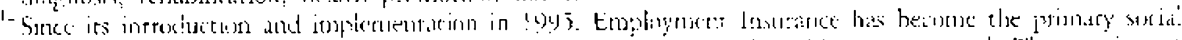

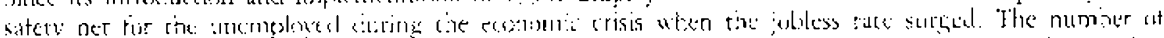

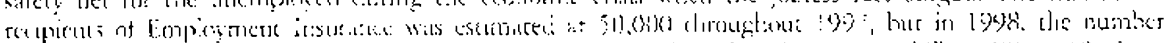

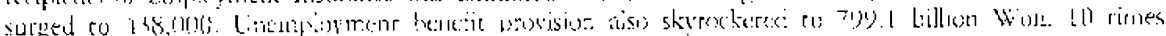

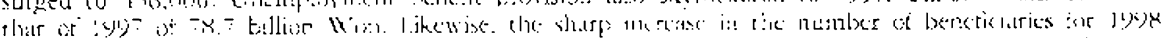

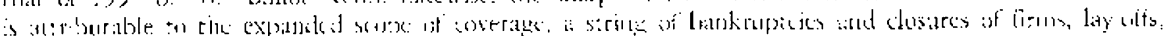

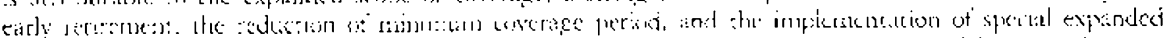

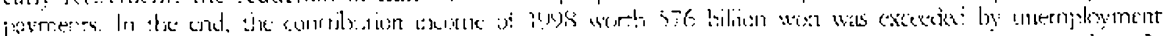

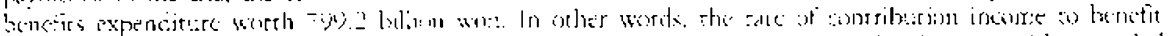

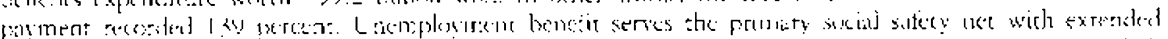

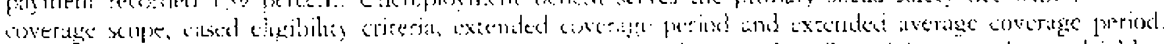

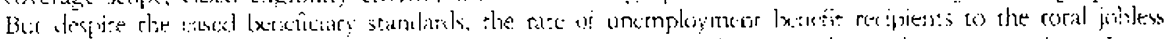

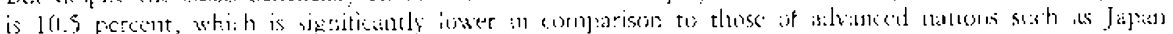

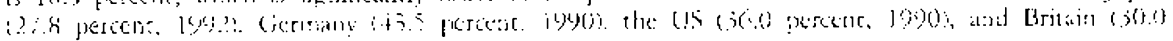
exrocite, (-jigs:

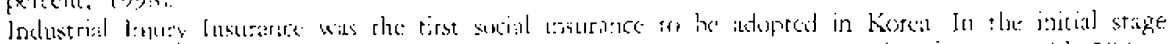

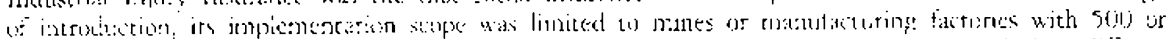

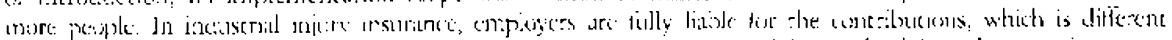

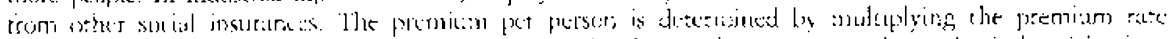

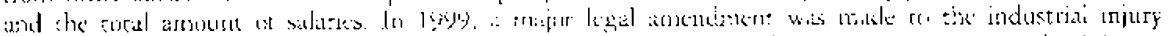

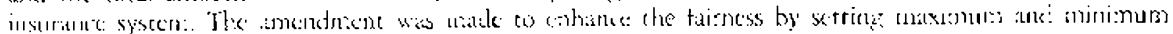

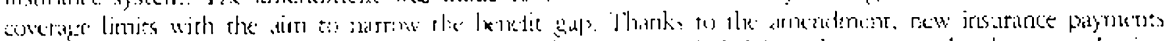

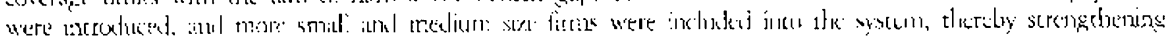
its relle ils al six jat. sattery nect.

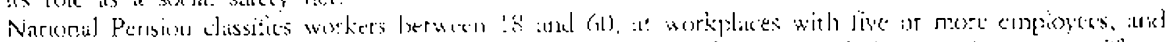

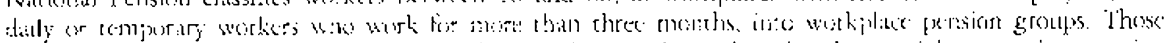

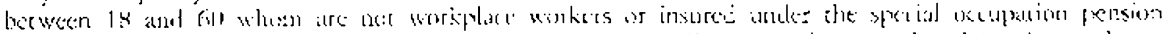

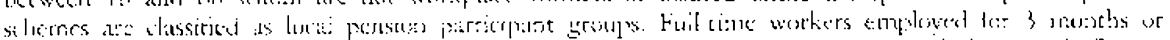

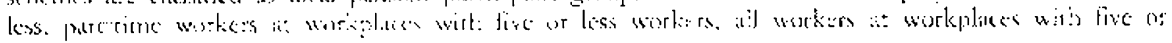




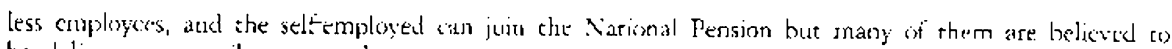
the delinguenr constiburests io the msurance.

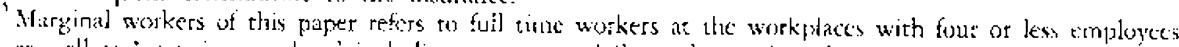
as well as 'part-time workers' inclieding tempxrasy daily workers. They share the common gronind: ehcis

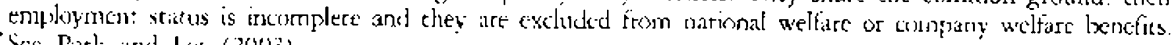
"Sce Patk atod lee (20013) 